\title{
ممارسات الأسرة الريفية لمواجهة أزمة كوفيد-19 \\ دراسة حالة بإحدى قرى محافظة القليوبية
}

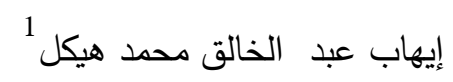

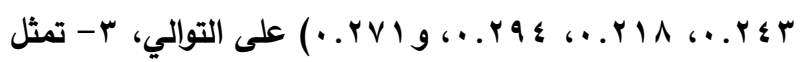
مواقــع التواصـل الاجتمــاعي، الأقـارب والجيـران أهـم مصــادر

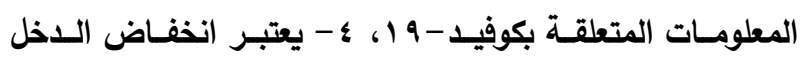

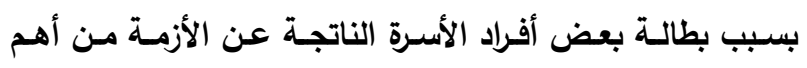

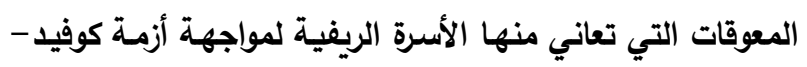
.19

الكلمات الدالة: الأسرة الريفية، كوفيد-9 19، وفيروس كورونا.

\section{المقدمة والمشكلة البحثية}

تُمثل فيروسـات كورونـا مجموعـة من الفيروسـات المغلفـة مع المادة الوراثية للحمض النووي، وقد أقر الباحثين بوجود

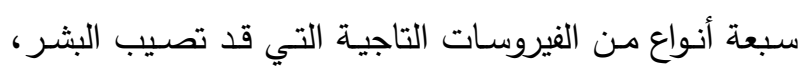

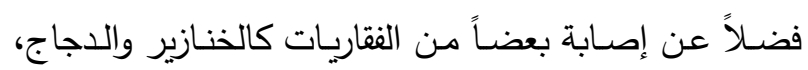
كما أن فيروسات كورونا تصيب البشر وتسبب أمراضاً متعلقة بالجهاز التتفي، ومن بينها فيروس كورونا المتلازمة التنفية

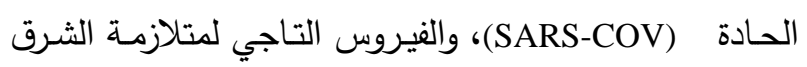

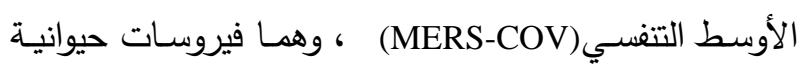
المنشأ وممرِضـة للغاية، وقد نتج عنها تفثي فيروس كورونـا الإقليمسي والعـالمي، حيث يستمر تكرار نسـخ المـادة الوراثيـة للحمض النووي من خلال توليد مجموعة متداخلة من جزيئات

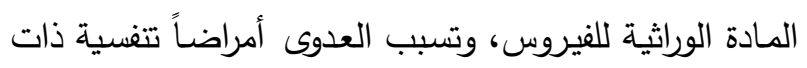
نتائج خفيفة ثم تنتشر لتحدث ضيق في التنفس بدرجة كبيرة، وقد ظهر هذا الفيروس والمُسمى بكوفيد-9 (، بمدينة ووهان

بالصين في نهاية عام 9 أ. (Unhale, et al, 2020: 109). وقد تُحدِث الإصـابة بهذا الفيـروس تغيـرات سـريعة في

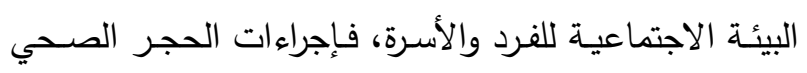

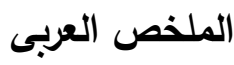

استهدف البحث التعرف على مستوى تنفيذ الأسرة الريفية

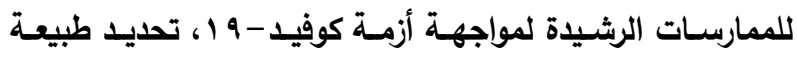

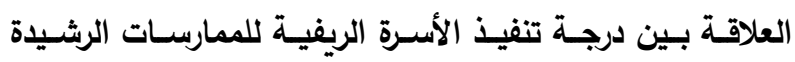

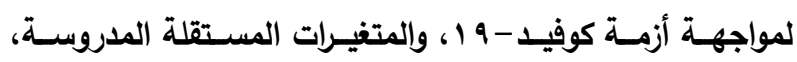
التعرف على مصادر معلومـات الأسرة الريفية المتعلقة بكوفيد -

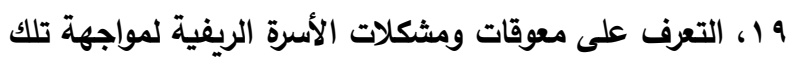

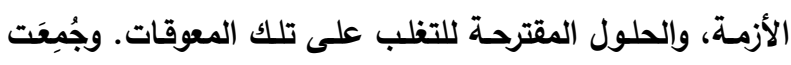

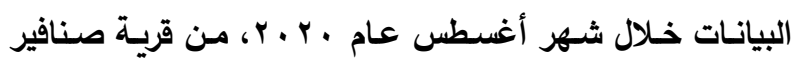
التابعة لمركز قليوب بمحافظة القليوبية بالمقابلة الثخصية لعينة

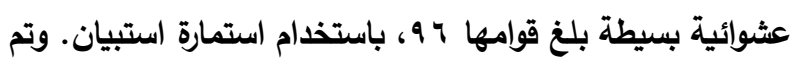

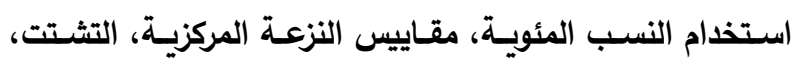

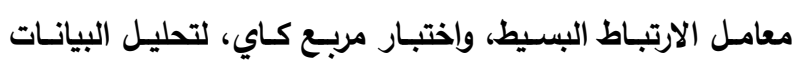

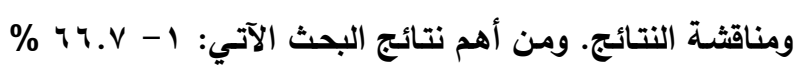

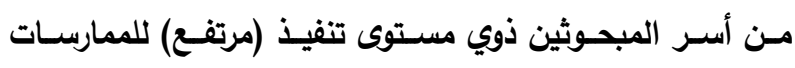

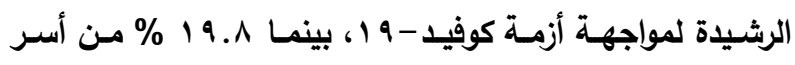
المبحـوثين ذوي مسـتوى تنفيــ (متوسـط) للممارســات الرشـيدة

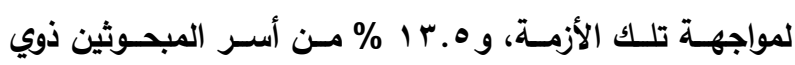

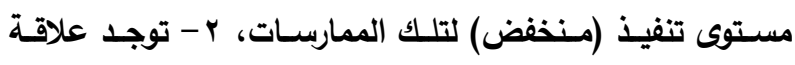
ارتباطيـة بـين درجـة تنفيـذ الأسـرة الريفيـة للممارسـات الرشيـيدة

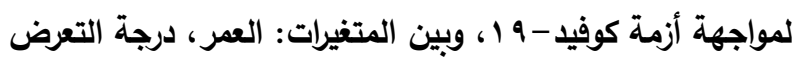

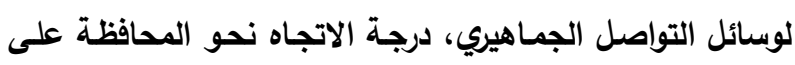

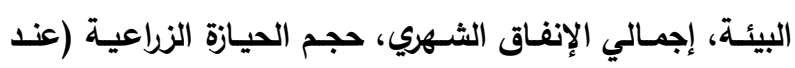

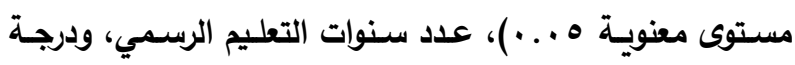

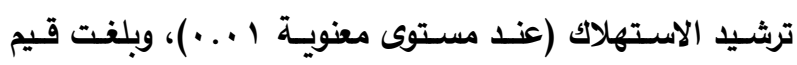

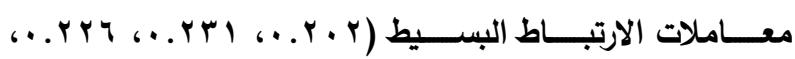

قسم الاجتماع الريفي والإرشاد الزراعي، كلية الزراعة، جامعة القاهرة dr_ehab_heikal@yahoo.com mob. 01065771850

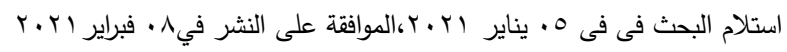




$$
\text { مجلة الإسكندرية للتبادل العلمى - (مجلد \& العدد () يناير - مارس IY.r }
$$

وفي ظل خطر صحي عالمي النطاق وشديد التأثير على

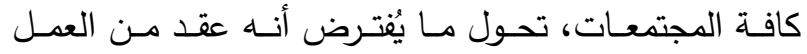
الدؤوب من أجل التتمية المستدامة إلى عقد من العمل الطارئ

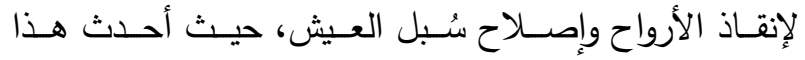
الفيـروس كورونــا أزمــة امتـدت لكافـة المجتمعـات، ولكنهــا أوضحت أن القطاع العام القوي والفعال هو خط الدفاع الأول

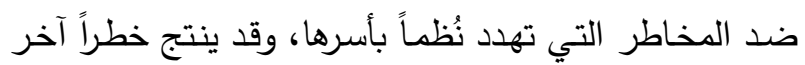
بانتشار الوباء متمثلاً في صراعات اقتصادية وضغوط مالية متفاقمـة، ولاحتـواء تلك التهديـدات المتصـاعدة والنابعـة مـن سـرعة انتثـاره، ينبغـي للجميـع العـل معـاً للحـد مـن تفـاهم الأزمـة، وخفض معدل الوفيـات، وينبغـي تقديم المسـاعدات

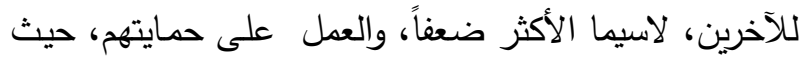

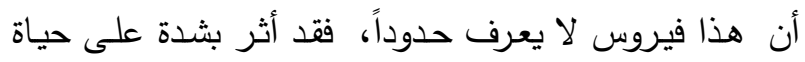

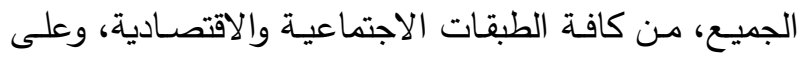
سُبُل معيشتهه، الأمر الذي يجعل تلك الحالة طارئة وشديدة الخطورة على الصعيدين المحلي والإقليمي، لذا تستدعي تلك

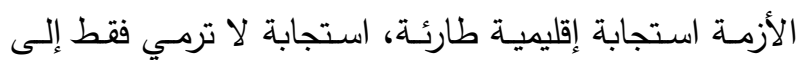

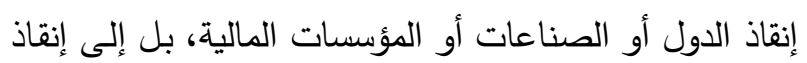
حياة مئات الآلاف من السكان، ويجب أن تتحور أي مبادرة للقضـاء على هذا الوبـاء حول رفاه السكان، وتضـامُن أركان المجتمع (الإسكوا، •r •r: r r). وفي ظل مواجهة الأسرة الريفية لتلك الأزمـة، سوف يتم

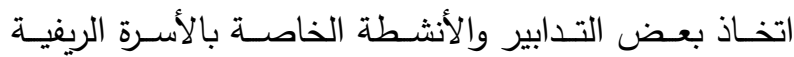
وأفرادهـا، الأمـر الذي يسـتدعي أن تلتزم الأسـرة بممارسـات رشيدة من شـأنها الاستمرار والصمود لمواجهة تلك الأزمـة، والمحافظة على كيانها وسـلامة أفرادها، حتى يتم تجاوز تلك الأزمة بأقل خسائر ممكنة، ومن هنا تأتي أهمية البحث الراهن بإلقاء الضوء على الأسرة الريفية وممارساتها الرشيدة لمواجهة

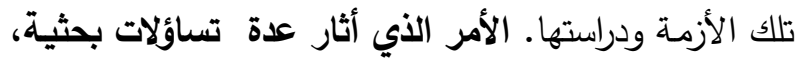
والتي يمكن توضيحها وصياغتها على النحو التالي:
كإغلاق المدارس، القيود على الحركة، وإحداث جمود الروتين اليومي، بالإضـافة إلى الضــوط الجديدة التي قد تقع على

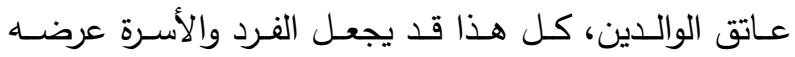
للضـغط النفسي والاجتمـاعي، ممـا قـ يـؤدي إلى اسـتخدام آليات سلبية للتعامل مع الوضع الذي تسبيت فيه تلك الأزمة، وقد يزيد الخطر الواقع على الأفراد والأسر الأكثر احتياجاً بسبب الظروف الاقتصادية المتردية، وينبغي على الحكومات

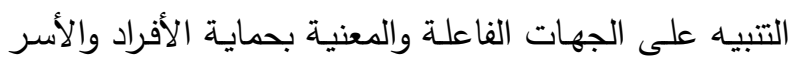

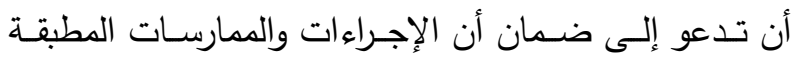
للتصدي لأزمة كوفيد-9 1 إتماشى مع المعايير الدولية وتلتزم بتوصـيات منظمـة الصـحة العالميـة (فرنانديز ، 9 1 ــ ب: 1. $(r$

وقد امتدت التداعيات الاقتصـادية لأزمـة فيروس كورونـا المسـتجد لقطاعـات عديـدة في مصـر ، ومسن بينهـا قطــاع الزراعة، وعلى الرغم من تأثر القطاع الزراعي-سلباً بسبب تلك مأك

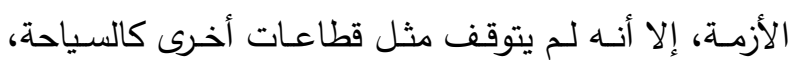
حيث يمثل القطاع الزراعي نحو ؟ ـا 1 ٪ من الناتج المحلي

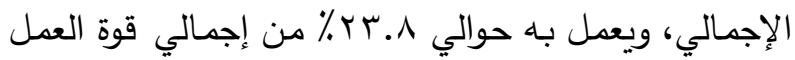

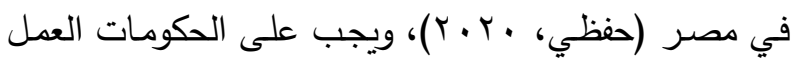
على توفير المـواد الغذائيـة والدوائيـة على اختلاف أنواعهـا للمواطنين، وإمدادهم بما يستجد من بيانات ومعلومات حول

تلك الأزمة.

وقد أسند أوجبرن التغيرات التي تحدث في الأسرة إلى عوامل خارجية بشكل أساسي، والعوامل الداخلية بشكل ثانوي

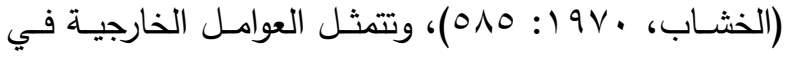
العمليات الخاصـة بالتصنيع والتحضر ، وقد تتمثل فيما ينتج عن البيئة الطبيعية المحيطة من أوبئة وأمراض، كرد فعل وله ناجم عن سلوك الإنسـان تجاه البيئة الطبيعية، الأكر الذي ينتج عنـه أزمـة تعيق روتين الحياة بالمجتمع، وتعتبر أزمـة فيروس كوفيد-9 1 مثال صارخ على إعاقة روتين الحياة لدي المجتمعات بشكل عام، والمجتمعات الريغية بشكل خاص. 
لمواجهـة أزمــة كوفيــــ9 (، وعلاقتهـــا بـبعض المتغيـرات الديموجرافيـة، الاجتماعيـة، والاقتصـادية، عـلاوةً على إثـراء الجانب النظري الخاص بهذا المجال، كما يمثل هذا البحث

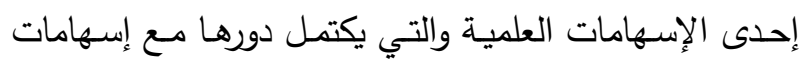

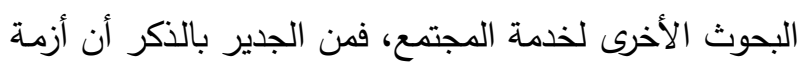
فيروس كوفيد-9 1 باتت أزمة محلية وعالمية في الوقت ذاته،

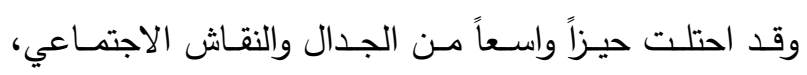
الاقتصادي.

أما على المستوى التطبيقي، ومـا قدر يصل إليه البحث

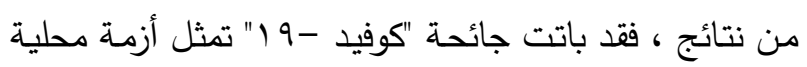

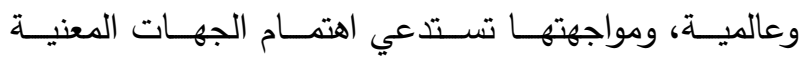
والحكومات بكافة الدراسـات والبحوث العلمية والتي يجب أن

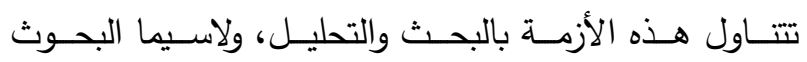
الاجتماعيـة الاقتصـادية، ويتــاول البحـث الـراهن ممارسـات

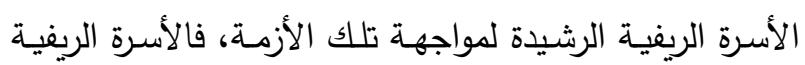

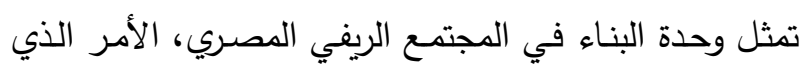
يجعل متخذي القرارات في حاجـة إلى أن يكونوا على درايـة

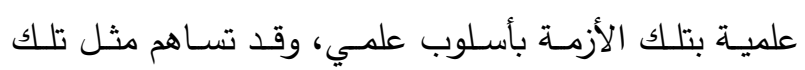
البحوث في تمكينهم من وضع رؤية أو خطة واضحة المعالم، للتعامل مع تلك الأزمة في الفترة القادمة بناءً على إحصـاءات

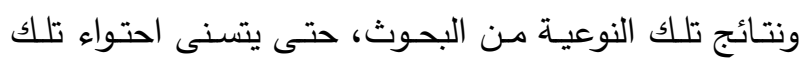

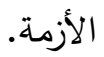

\section{الإطار النظري والاستعراض المرجعي}

تمثل الأسرة وحدة بنـاء المجتمـع، فهي أسـاس وجود المجتمع، ومصدر الدعامة الأولى لضبط السلوك، والإطار الذي يتلقى فيه الإنسان أول دروس الحياة الاجتماعية، وفي مجال دراسة الأسرة وأهميتها تظهر موضوعات على قدر كبير من الأهميـة، والتي قد تتطرق إلى النواحي الاجتماعيـة،

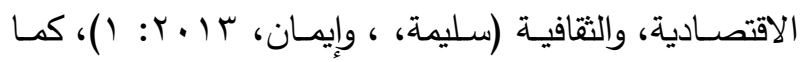
تعد الأسرة نتاجاً للأنماط الثقافية المتوارثة والمكتسبة من طرفي

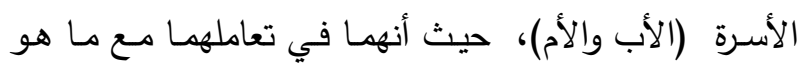

1- ما هو مستوى تتفيذ الأسرة الريفية للممارسات الرشيدة

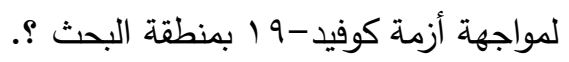
r- ما هي طبيعة العلاقة بين درجة تتفيذ الأسرة الريفية

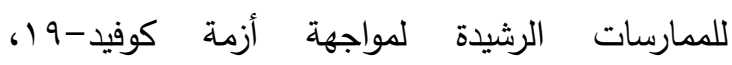
والمتغيرات الديموجرافية، الاجتماعية، والاقتصادية المستقلة المدروسة بمنطقة البحث ؟. r- ما هي مصادر معلومات الأسرة الريفية المتعلقة بفيروس

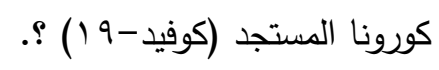

ع- ما هي المعوقات التي تعاني منها الأسرة الريفية لمواجهة أزمة كوفيد-9 1 من وجهة نظر المبحوثين؟. 0- ما هي الحلول المقترحة للتغلب على المعوقات التي

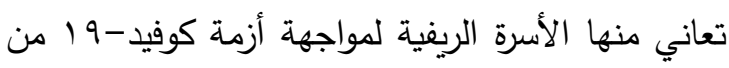
وجهة نظر المبحوثين؟.

\section{أهداف البحث}

1 - قيـاس مستوى تتفيذ الأسـرة الريفيـة للممارسـات الرشيدة لمواجهة أزمة كوفيد-9 1 بمنطقة البحث.

r- تحديـد طبيعـة العلاقـة بـين درجـة تتفيـذ الأسـرة الريفيـة

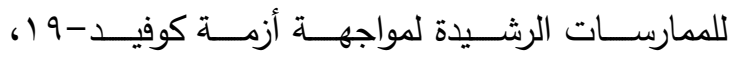
والمتغيـرات الديموجرافيــة، الاجتماعيــة، والاقتصــادية المستقلة المدروسة بمنطقة البحث. r- التعرف على مصـادر معلومـات الأسـرة الريفيـة المتعلقة

$$
\text { بفيروس كورونا المستجد (كوفيد-9 ()). }
$$

؟- التعرف على المعوقات التي تعاني منها الأسرة الريغية لمواجهة أزمة كوفيد-9 19 من وجهة نظر المبحوثين. 0- التعرف على الحلول المقترحة للتغلب على المعوقات التي تعاني منها الأسرة الريفية لمواجهة أزمة كوفيد-19 من وجهة نظر المبحوثين.

\section{الأهمية التطبيقية للبحث}

يهتم البحث الراهن - والذي يدخل في نطاق البحوث

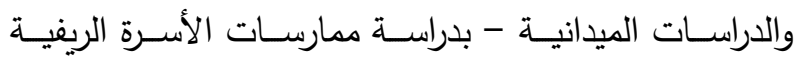


- المرحلة الثانية (مرحلة الأسرة الأمومية): وهي مرحلة أكثر

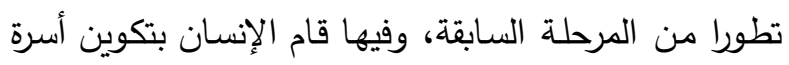

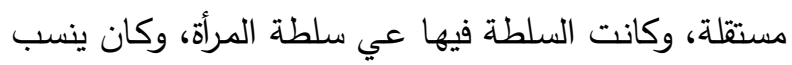
الطفل لأمه في هذه المرحلة.

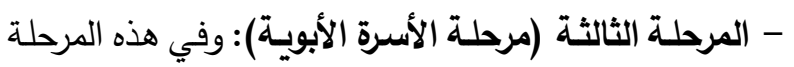

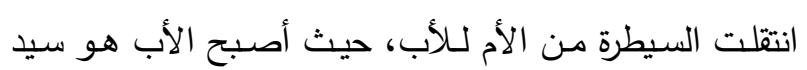

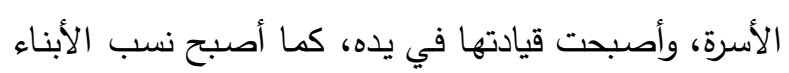
يعود للأب، وهذا الأمر قد استمر إلى الآن.

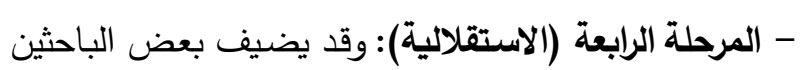

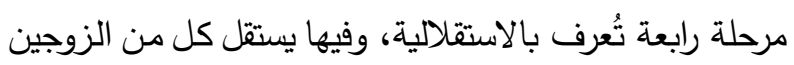

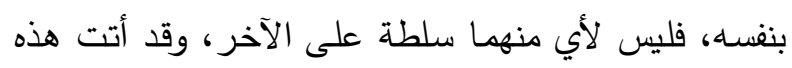
المرحلة كنتيجة للتطور الاقتصادي، حيث أصبح المنزل مُلتقي

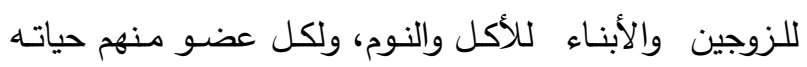

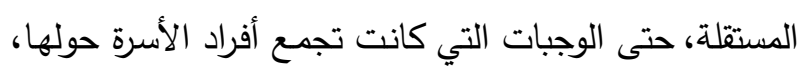

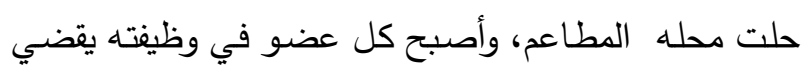

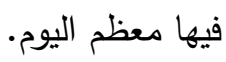

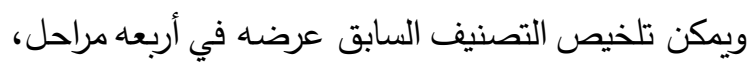

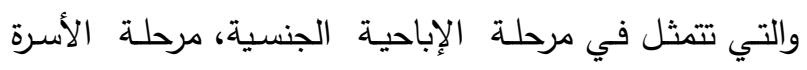

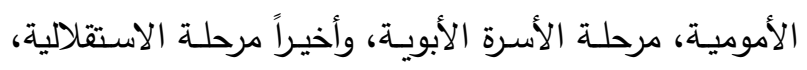

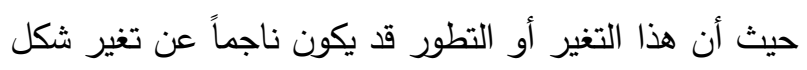

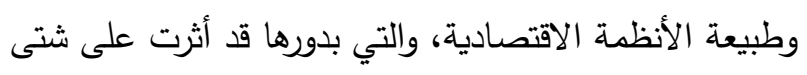

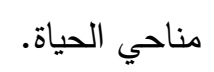

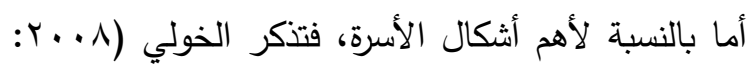

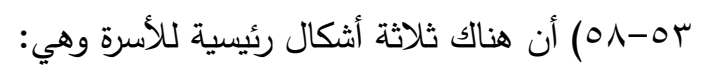
1. الأسرة النواة: وهي التي تتكون من زوج وزوجة وما قدان الد يضاف إليهما من أطفال متزوج. r. أسرة الجمع: ويشير هذا الدفهوم إلى ظاهرتين، الأولى هي

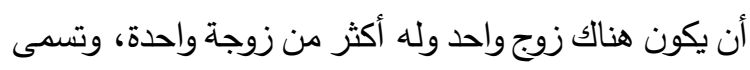

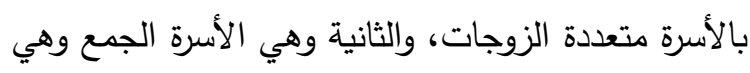

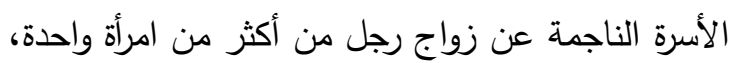
ولكل امرأة أولادها الذين أنجبتهم من الزوج نفسه.
موروث ومكتسب يؤديان إلى بناء نمط سلوكي وثقافي مميز لكل أسرة(Burgess and Locke, 1945: 281). لذا كانت الأسرة

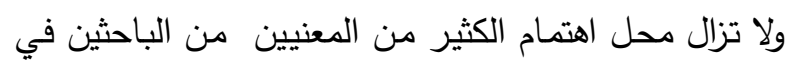

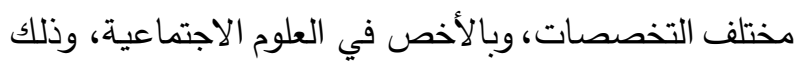

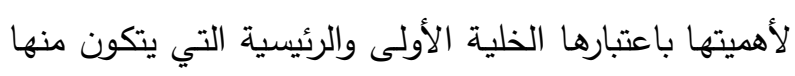

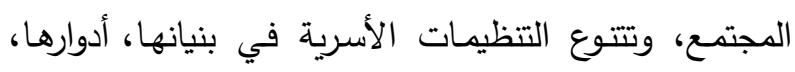

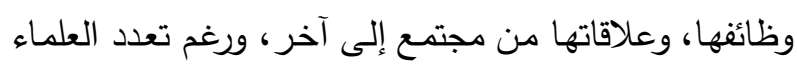

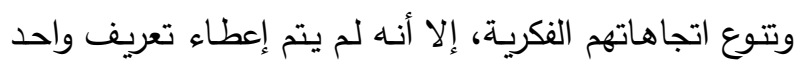

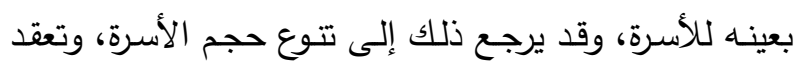

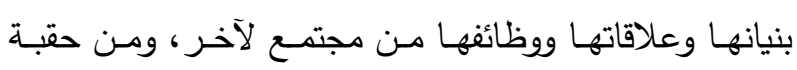

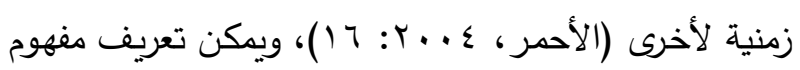

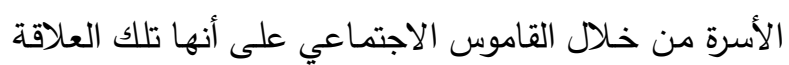

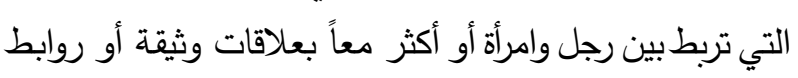
قرابة، حيث يثعر أعضائها البالغين بالمسئولية تجاه الأطفال

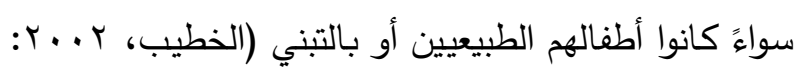

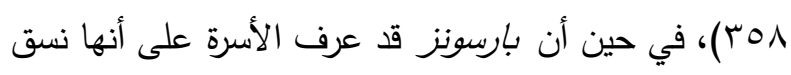

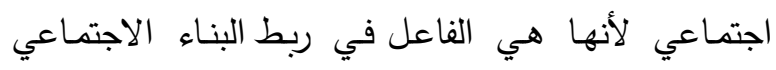

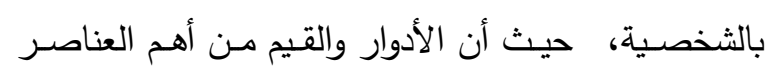

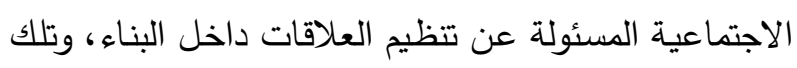

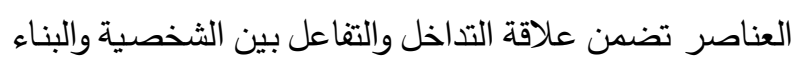

$$
\text { الاجتماعي (سعيد، .9191: } 7 \text { ـ ()). }
$$

ومن الملاحظ أن تعريف بارسونز لففهوم الأسرة قد تم

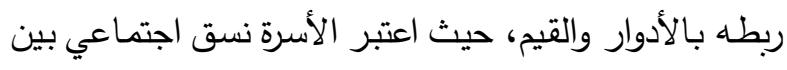
أنساق اجتماعية عديدة تتفاعل معاً لتكون البناء الاجتماعي الاعني

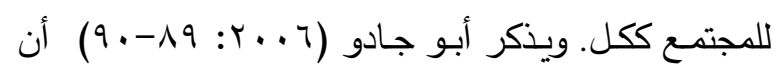

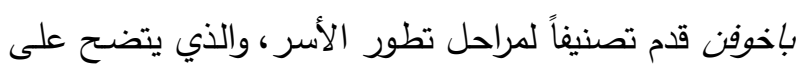

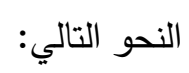

- المرحلة الأولى (الإباحة الجنسية): وقد عاش الإنسان في

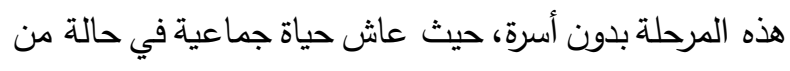
الثيوعية غير المنظمة في الملكية أو الحياة الجنسية، وقد

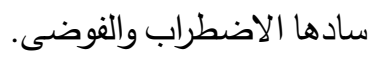


حقوقه وواجباته التي تساعده على الصحة النفسية والتكيف هم هُ مع وسطه الاجتماعي. ع ـ الوظيفة الاقتصادية: وقد حدث لهذه الوظيفة تطور كبير بوصفها وظيفة أسرية، وقد يكون من أبرزها خاصـة في في وني المجتمعات الريفية، والتي لم تعد كعهدها في الاكتفاء بذاتها اقتصاديا، وهجرة أفرادها إلى المدينة. ونلاحظ من خـلال العرض السـابق أن هناك تغيرات قد لحقت بالأسرة بصفة عامـة، حيث أصبحت هناك مؤسسات

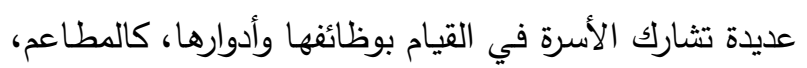
والأندية، ولكن في هذا التعدد قد يغيب دور الأسرة في رقابة

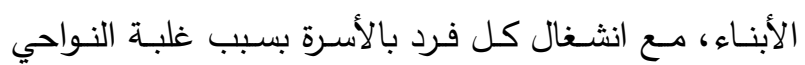

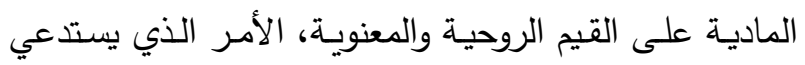
تقصي تلك التغيرات بشكل علمي دقيق. ومن الجدير بالذكر تعدد العوامل التي قد تتسبب في إحداث تغيرات في الأسرة ، وقد ظهر اتجاه تفسير التغيرات

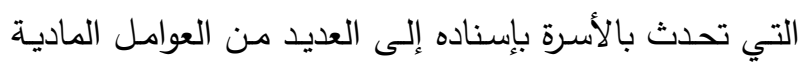
عند كل من أوجبرن، وماركس، في حين أن أوجست كونت، ، وماكس فبر قد أرجعا ذلك التغير إلى جوانب عقليه أو فكريـة، حيث أن التغير الأسري نابع أساساً من التغير الفكري، وهذا التغير الفكري نـاتج عن التغير المـادي (الخشـاب، • و I I: 010). الأمر الذي يقد يؤثر على سلوك الأسـرة وأعضـائها، وقد يكون هذا التغير ضئيل أو بالغ، وذلك يتوقف على نوع وقوة العامل المتسبب في إحداث هذا التغير ، ويمكن تعريف السلوك على أنه حالة من التفاعل بين الكائن الحي ومحيطه

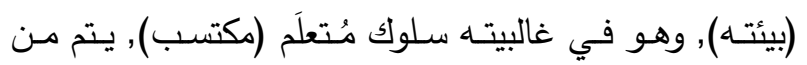

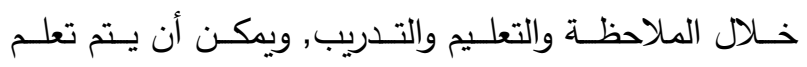
السلوكيات البسيطة أو المعقدة. وكلما أتيح لهذا السلوك أن وند يكون منضبطاً وظيفيا ويلقى قبولاً, كلما كان إيجابياً, وبتكراره يتحول إلى "عادة سلوكية " تؤدي غرضها بتلقائية، ويُنظر إلى تي

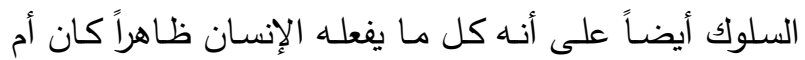
غير ظـاهراً، وينظر إلى البيئة على أنها كل مـا يؤثر في r. أسرة العائلة (الممتدة): وتتكون من أسرتين أو أكثر تفرعتا عن العلاقة أباء -أبناء، أو هما امتداد لهذه العلاقة أكثر من تفرعها عن العلاقة الزوجية، أو هي اجتماع أسرة شخصين (زوج وزوجة) مع أسرة الأهل.

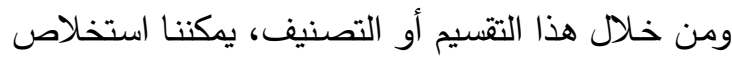
أنه تم حصر أثكال الأسرة في ثلاثة أشكال متمثلين في الأسرة النواة، أسرة الجمع، والأسرة الممتدة أو أسرة العائلة،

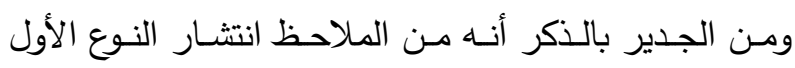

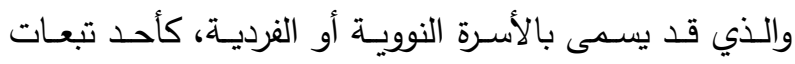

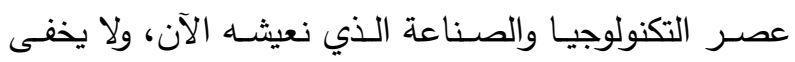
على أحد أن هذا الأثر قد امتد للمجتمعات المحلية الريفية بدرجة كبيرة.

ومـن الجـدير بالـــكر أن الأســرة ذات وظـائف وأدوار

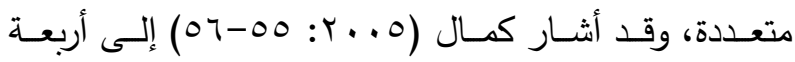
وظائف أساسية للأسرة يمكن توضيحها على النحو التالي: 1 ـ الوظائف البيولوجيةة: تقلصت وظائف الأسرة من وحدة اقتصادية تتتج للمجتمع كل ما يحتاجه، وأصبحت وظيفتها البيولوجية تتلخص في الإنجاب وما يسبقه من علاقات مشروعة، ضرورية لاستمرار الكائن البشري. r ـ الوظيفة النفسية: من المعروف أن الإنسان يحتاج للغذاء لينمو ويكبر ، ولكن حتى يكون هذا النمو غير ناقص،

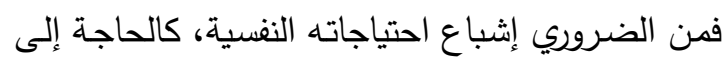
الحب، التقدير ، والأمن والأمان، وهذا لا يمكن أن يوفره إلا

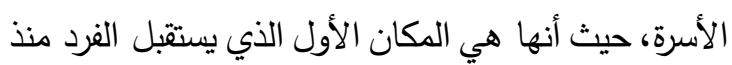
ولادته. r. الوظيفة الاجتماعية: وتتجلى في التتشئة الاجتماعية للأبناء، التي يبدو تأثيرها بالأخص في السنوات الخمس الأولى من حياة الطفل، ففي هذه السنوات يتم تربية الطفل اجتماعيا وتدريبه وتعليمه على مختلف النظم الاجتماعية، وكما تتضمن إعطاء الدور والمكانة المناسبين، وتعريفه بذاته، وبناء ضميره وتعليمه المعايير الاجتماعية ليعرف 


$$
\text { مجلة الإسكندرية للتبادل العلمى - (مجلد ؟ العدد () يناير - مارس (Y.r }
$$

عميقـة الأثـر ذات طبيعـة شـديدة، وقــــــــــل الأزمــة السطحية إلى عميقة في حالة الإهمال. r. أزمـات مفاجئةة: وتحدث بشكل عنيف وفجـائي وتخـرج المسببات المؤدية لها عن الطابع المألوف. r. الأزمــة الزاحفـة: وهي تتمو ببطء، ولكنها محسوسـة ولا يمكن لمتخذ القرار وقف زحفها نحو قمة الأزمة. ء. أزمات المتراكمة: وهي التي يمكن توقع حدوثها، حيث أن عملية تكوينها وتفاعل أسبابها تأخذ وقت طويل قبل أن لن تتفاقم وتتطور مـع الزمن، ممـا يتيح الفرصـة للتقليل من

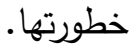
هـ أزمـات يمكـن التبـؤ بهـا: وهـي تحدث نتيجـة أسـباب

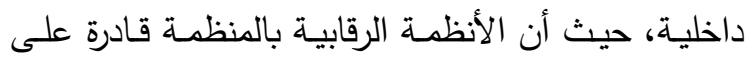
رصدها والتعامل معها. 7. أزمات لا يمكن التنبؤ بها: وهي تحدث بسبب التغييرات

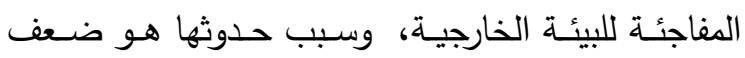
مراقبة وتفحص البيئة الخارجية بشكل فعال. V. أزمـات روتينيـة: تحدث بشكل دوري، وتتتج عن تعديل القوانين والأنظمة.. ^. أزمـات إسـتراتيجية: حيث التدهور والضــور في قدرة المنظمة، ويتضح ذلك التهديد عندما تكون المنظمة غير قـادرة على احتـواء مـا يحدث مـن متغيـرات في البيئة

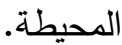

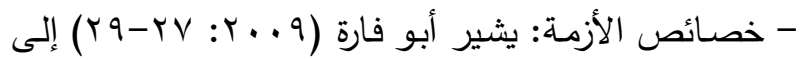
خصائص الأزمة، والتي يمكن توضيحها فيما يلي: ا. التـــاقض الواضــــح في البيانات اللازمة أثناء وقوع الأزمة، وينعكس ذلك في صدورة من عدم وضوح الرؤية

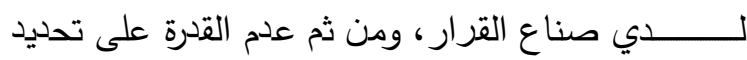
الاتجاهات السليمة لصناعة القرارات الفاعلة.
السلوك, فالسلوك إذن عبارة عن مجموعـة من الاستجابات, أما البيئة فينظظر إليها على أنها مجموعة من المثيرات، وقد يكون السلوك مقبولاً أو غير مقبولاً, بناءً على المعايير التي لئي يُحتَكم إليها أو إلى المنظومة القيمية التي تقرر هذا السلوك

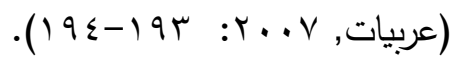

- Crisis Concept ماهية الأزمة -

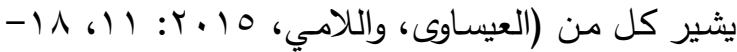

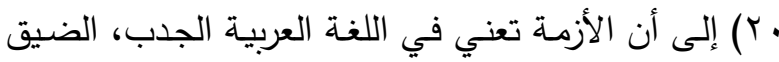
والثـدة، والضـائقة في كـل شـيء متعلـق بتكـاليف الحيـاة، ومصـطلح الأزمـة (Crises) يعنـي لحظــة القـرار ، واللحظــة لبمصيرية أو الزمن الذي يتم فيه اتخاذ القرار، كما تشير إلى لـى معنى التغيير المفـاجئ نحو الأسوأ، وتراكم الأزمـة قد ينتج عنها نتائج غير متوقعة على مستوى النظام بشكل جزئي أو كلـي، وبتضـخم الأزمـة قد يحدث التأثير في شـتى أجـزاء النظام، لذا تتأثر الأنشطة والعمليـات الخاصــة بالنظـام وقد يمتد ليؤثر في مستقبل النظام بأكمله. ويمكن تعريف الأزمـة استتاداً إلى الأدبيات الخاصة بها على النحو التالي: ا ـ تعـرف إداريـاً بأنهـا ظـاهرة لا تتميز بالاسـتقرار، وتمثل تهديداً مباشراً لبقاء واستمرار المنظمة.

r. تعني حدث سلبي يصعب تجنبه، لأنها تتصف بعنصر المفاجأة، نقص المعلومات، وتسارع الإحداث.

r. كمـا أنهـا لحظــة مفزعـة ومحيـرة، حيـث تتصـف بنـدرة البيانات الصحيحة، وقصور المعرفة.

ء. وهـي موقف خـارج عـن السـيطرة وتحـول فجـائي عـن السلوك المعتاد، يؤدي إلى خلل في المجتمع، ومواجهته يتطلب اتخـاذ قـرار سـريع ومحـد رغـم ضـيق الوقت. وتتعدد أنواع الأزمات حسب رؤى الباحثين، وهذا التعدد

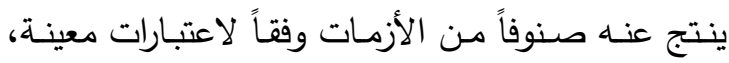
ويمكن تصنيف الأزمات حسب الاعتبارات التالية: 1 ـ أزمات سطحية: وتحدث بشكل مفاجئ ولا تشكل خطورة كبيرة، وتتتهي من خلال التعامل مـ أسبابها، وقد تكون 
ومسن ثم تبدأ في الانحسـار والتقلص، ولكن قد تتجدد بعض الأزمات عندما يفشل الصدام في تحقيق أهدافه. ه. مرحلـة الاختفاء: وتصل الأزمة إلى هذه المرحلة عندما تفقد بشكل كبير قوة الدفع المولدة لها أو لعناصرها التي تتتمي إليها، ومن ثم تتلاشى مظاهرها، وينتهي الاهتمام

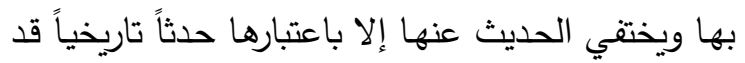

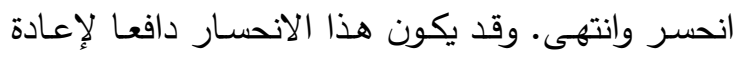
البناء والذي يتصل أساساً بعلاج آثار الأزمة. وليس بالضرورة أن تعصف الأزمات بالذظام الإقتصادي على المستوى الكلي أو المستوى الجزئي بصورة فردية، أي أنه قد يتعرض الاقتصاد على المستوى الكلي - في كثير من الأحيان - إلى أكثر من أزمة، وهذا ما يطلى لاق عليه تزامن الأزمات، حيث توجد شواهد عديدة في التاريخ الإقتصادي على الأزمات التي تعرض لها الاقتصاد الدولي، ومنها أزمة البطالة والتي تزامذت مع أزمة التضخم العالمي،

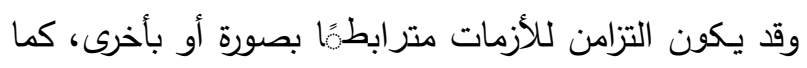
يمكن أن يكون هذا التزامن غير مترابط مثل الأزمة المالية العالمية التي تعرض لها الاقتصاد العالمي في الثمانينات،

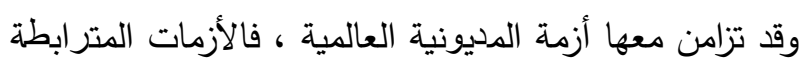
هي التي تحدث بسبب الصلة الوثيقة للعناصر والأحداث وتفاعلها معاً، أما الأزمات غير المترابطة فهي حالة قد تحدث في المنظمة أو الوحدة الاقتصادية، وينجم عنها وقوع أزمتين أو أكثر في نفس الوقت لأسباب مختلفة غير متصلة - (Mitroff and Pearson, 1993: 48) يبعضها البعض

\section{- ماهية فيروس كورونا المستجد (كوفيد -9 1):} فيروسات كورونا هي مجموعة من الفيروسات المغلفة مـع

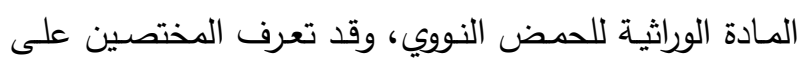

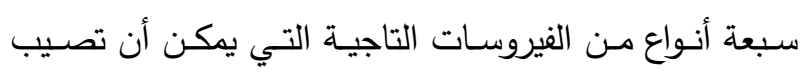

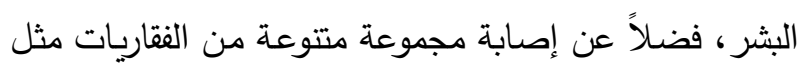

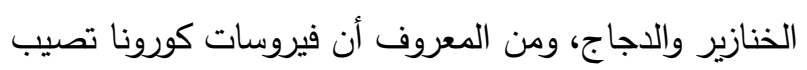

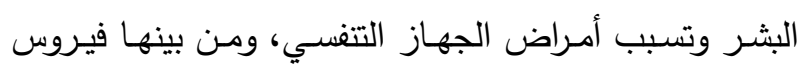

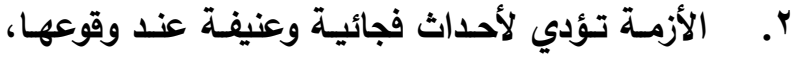
وتجذب انتباه كـل الأطــراف المعنيــة علـى المسـتويين الاجتماعي والاقتصادي.

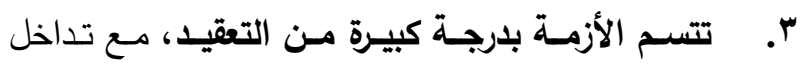
عناصـر عديدة، وحدوث تشـابك وتتـاقض بين الشـركاء

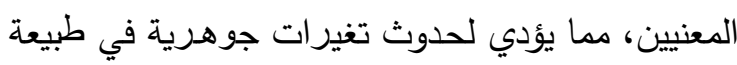
العلاقات القائمة، وتكوين علاقات جديدة. ؛. وجود حالـة من الخوف بكل أجزاء المجتمع، وسببه العجز في تقدير مستقبل النشاط الاقتصادي للمجتمع.

-The Stages of Crisis مراحل الأزمة -

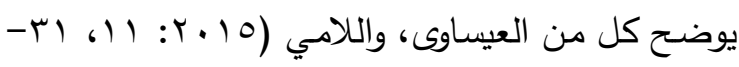
ع آ) أن هناك خمس مراحل أساسية تمر بها الأزمـة، وفيما يلي توضيح لتلك المراحل: ا ـ مرحلـة النشهوء : حيث تبدأ الأزمـة في الظهور لأول مرة بشكل مبهم ويصـاحبها إحساس بالقلق، ويرجع هذا إلى

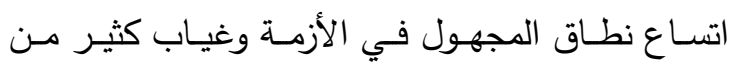
المعلومات حول أسبابها. r. مرحلة النمـو والاتسـاع: في حالة مـا إذا لم متخذي القرار إلى خطورة الأزمة في مرحلة ميلادها، تتمو وتدخل في

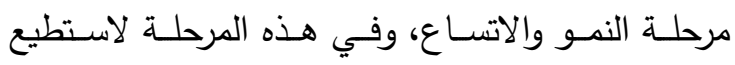
متخذي القرار نكران وجودها أو تجاهلها. r. مرحلة النضج: ونادراً ما تصل الأزمة إلى هذه المرحلة، ولكنها قد تحدث عندما يكون متخذ القرار على درجة كبيرة من التجاهل، ومن ثم تزداد القوى المتفاعلـة في المجتمع وتغذي الأزمة النامية بقوى تزيد من آثارها.

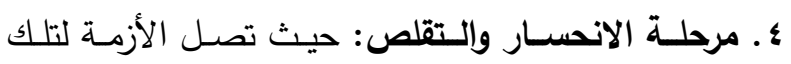

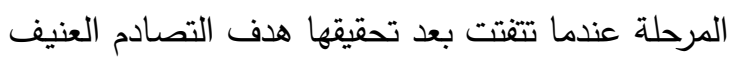
مع المعنيين بها، بالإضافة لأفراد المجتمع ، فبعد مرحلة

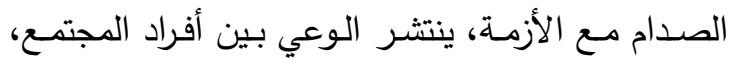


من الفيروسات التي يمكن أن تصيب الطيور والثدييات، بما

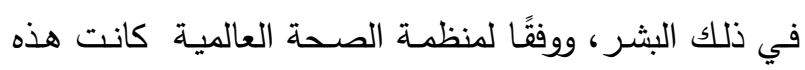
الفيروسـات مسئولة عن العديد من انتشار كوفيد-9 1 حول ولئ العالم (Unhale, et al, 2020: 109-110). ومن الجدير بالذكر أن الزراعة تُعد من أهم نظم الإنتاج

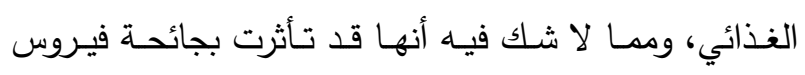

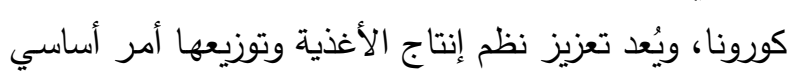
لمكافحة الجوع، وهو أمر ينطوي على مواجهة أي وباء أينما

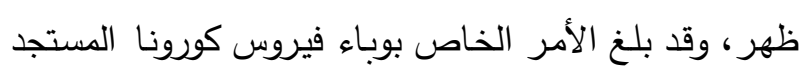
إلى أن أصبح أزمة صحية عالمية، وتؤدي منظمة الأغذية

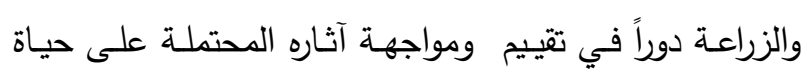

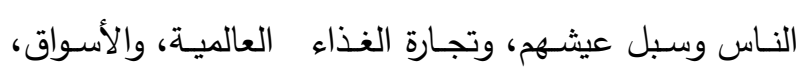

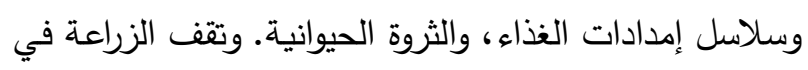

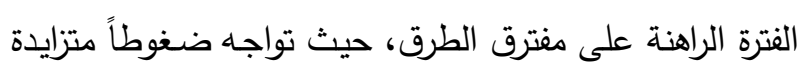
لتوفير أغذيـة كافيـة لعدد متزايد من السكان، وذلك لمواجهة

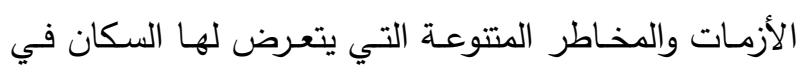
مختلف دول العالم، حيث أن هناك تفاوت على الصسعيدين

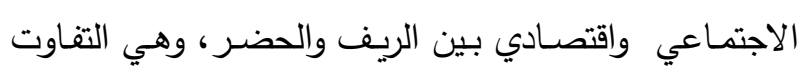
يتزايد لمستوى غير مسبوق، وفي ضـوء هذه التحديات، تم

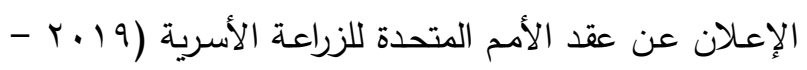

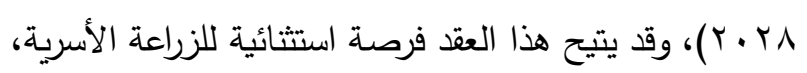
وزيـادة قدرتهم على تطـوير اسـتراتيجيات جديـدة وتقديم استجابات مبتكرة للتحديات الاجتماعية، البيئية، والاقتصادية الناشئة، وتحقيق تحولات مجدية للنظم الغذائية، حتى تسهر

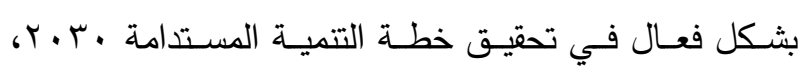

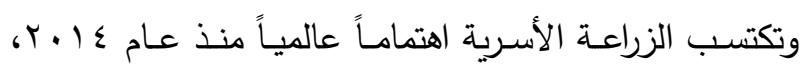

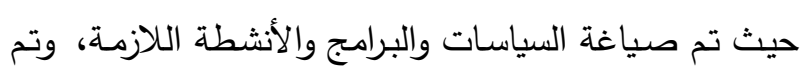
إنثاء منصات متعددة الجهات الفاعلة من أجل الحوار حول

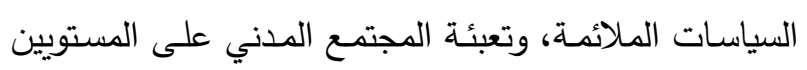

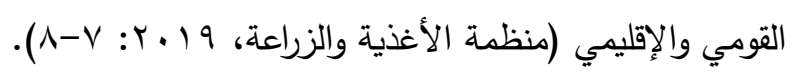

كورونا المتلازمة التتفية الحادة (SARS-COV)، والفيروس ، التاجي لمتلازمـة الثرق الأوسط التنفسي(MERS-COV) وهما فيروسات حيوانية المنشأ وممرِّة للغاية، وقد نتج عنها تفشي فيروس كورونا الإقليمي والعالمي، يستمر تكرار نسخ

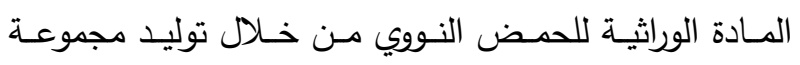

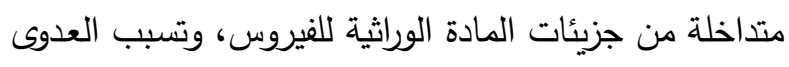
أمراضًا تتفسية ذات نتائج خفيفة ثم تشتد لتحدث ضيق في

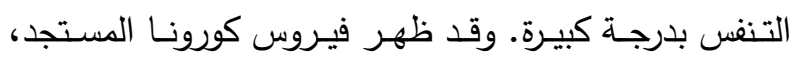
والمُسـى كوفيد-19 1 ، في وهـان بالصسين في نهايـة عـام

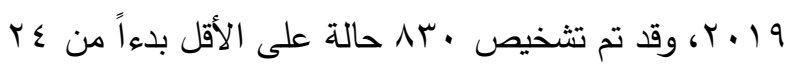

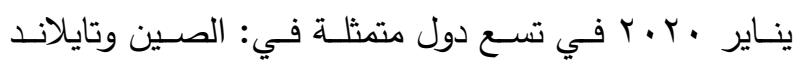

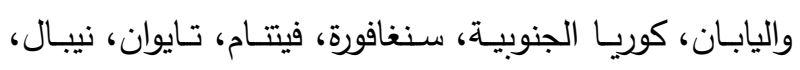
والولايات المتحدة الأمريكية. وقد بلغت عدد الوفيات حينها

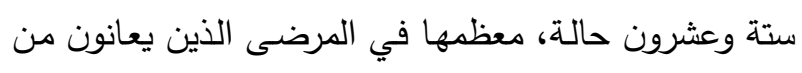
مرض كامن وخطير ، على الرغم من أن العديد من التفاصيل حول هذا الفيروس - مثل مصدره وقدرته على الانتشار بين البثـر - لا تـزال غيـر معروفـة، ويبـدو أن تزايـد الأعـداد

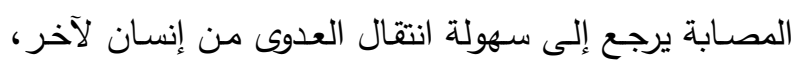

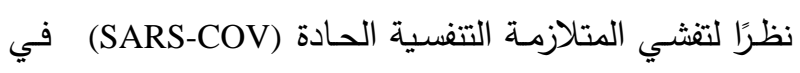

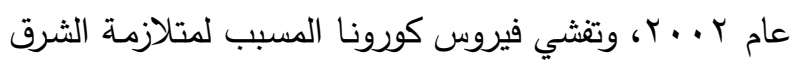
الأوسط التنفسية (MERS-COV) في عام r I ا • r، ويعتبر كوفيد-19 الهو ثالث فيروس كورونـا يظهر بين البشر في

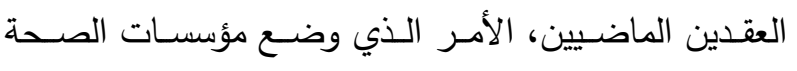
العامـة العالميـة في حالتة التأهب القصـوى، وقد استجابت

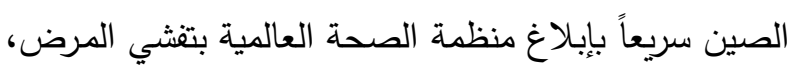

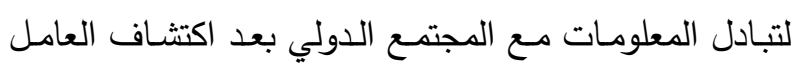

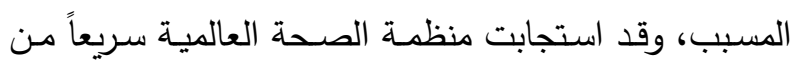

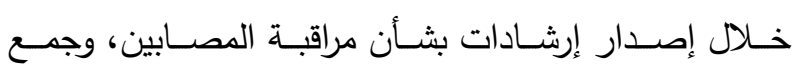

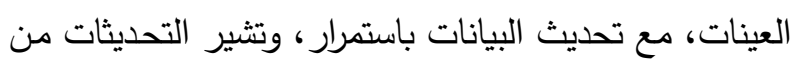

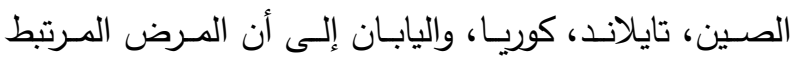

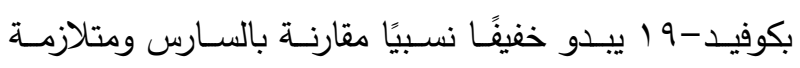
الشرق الأوسط التنفية، وتثكل فيروسات كورونا عائلة كبيرة 
في إسـهامات هربرت سبنسر ، حيث شبه المجتمع بالكائن العضوي، وأكد على وجود التساند والاعتماد الوظيفي المتبادل بين نظم المجتمع في كل مراحل التطور الاجتماعي، بغرض وجل إيجاد حالة من التوازن تساعد المجتمع على بقائه واستمراره (أبو زيد، \&19 19 1: 7 1 (1))، حيث يعالج الأنساق الواسعة نسبيا

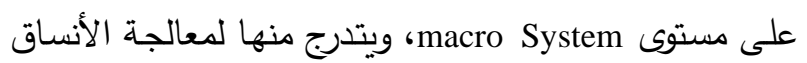
الصغيرة نسبيا أي على مستوى micro System، مثل الأسرة

الريفية، وتتمثل الفروض الوظيفية لتلك النظرية فيما يلي: ا. يجب إثباع المتطلبات الوظيفية الأساسية عند مستوى معين حتى يستمر النسق الأسري.

r. كل نسق فرعي وظيفي يتخصص في إثباع جزء معين من هذه المتطلبات.

r. تؤدي الأسرة باعتبارها نسق فرعي احد هذه المتطلبات،

$$
\text { والمطلوب إشباعها. }
$$

ء. الأسرة نسق اجتماعي ذو متطلبات وظيفية تتاظر تلك

$$
\text { الموجودة في الأنساق الأكبر · }
$$

๑. تعتبر الأسرة اصغر وحده بنائية، و بالتالي فإن لها خصائص تميزها عن الجماعات الأخرى.

- المتطلبات الوظيفية ونسق الأسرة: وتتمثل أهم المتطلبات الوظيفية اللازمة لاستمرار نسق الأسرة فيما يلي: ا. التكيفف:أي تكيف نسق الأسـرة مـع البيئة الاجتماعيـة لها، فالتبادل بين الأسرة والاقتصـاد يكون بالتحاق أفراد الأسرة بالعمل للحصول على أجر، حيث تواجها الأسرة الظروف الاقتصادية بالعمل واكتساب المهارات. r. تحقيق الهدف: النسق الاجتماعي (الأسرة) يحتاج إلى سـبب للبقـاء، وهـذا يعنـي أن وجـود أهـداف (فرديـة،

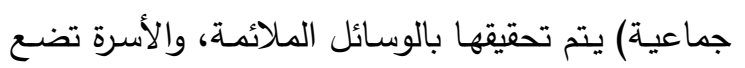
في مقدمة وظائفها تحقيق هذه الأهداف.

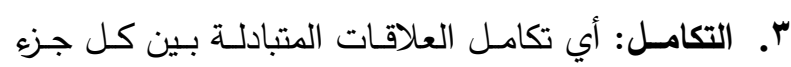
بالنست، وقد يُنْظر للمجتمع المحلي كنست فرعي من

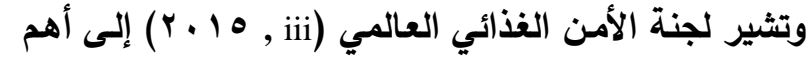
المبادئ التي تلتزم بها للعمل على تحسين الأمن الغذائي والتغذية في ظل الأزمات الممتدة، والتي يمكن إيضاحها كما يلي: - معالجة تدهور الحالات الحرجة وبناء القدرة على الصمود. - تلبية الاحتياجات الإنسانية الفوريـة وبناء سبل كسب عيش قادرة على الصمود. - الوصول إلى السكان المتضـررين، مـع التركيز على إثباع الاحتياجات الغذائية.

- إدارة الموارد الطبيعية على نحو مستدام، والحد من أخطار الأزمات الممتدة.

- - - المساهمة في حل الأسباب الكامنة لانعدام الأمن الغذائي ونقص التغذية في الأزمات الممتدة. - تعزيـز فعاليـة الحوكمـة الوطنيـة والمحليـة، بالإضـافة إلى لـ تعزيز التمويل الفعال. - المداخل والتوجهات النظرية للبحث: يُعَد الاتجـاه البنـائي الوظيفي أحد المـداخل الأساسية لدراسة الأسرة وكذلك المجتمع، حيث تنظر للمجتمع على أنه بناء مكون من عدة أنساق، ولكل نسق دور ووظيفة محدده، وتعتبر الأسرة من أهم تلك الأنساق، فهي تُعرف على على أنها

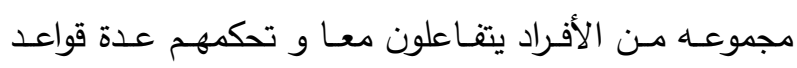
لتحقيق هدف معين، لضـمان بقائها، وتستخدم هذه النظريـة

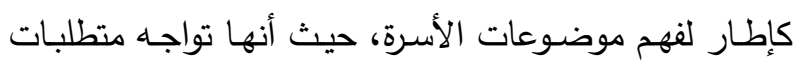
عديدة نظراً لتعدد الاهتمامـات داخل الأسرة، وكذا التأثيرات المنبعثة مـن الأنسـاق الأخرى على الحيـاة الأسـرية، وتأثير الأسرة كمؤسسـة على تلك الأنساق، ويدور المحور الرئيسي الأيسي

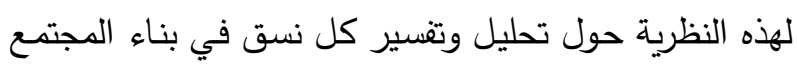
و إبراز الطريقة التي تترابط فيها معاً، ويسمى هذا بالتحليل الوظيفي، أي تحليل هذه الأجزاء وتفسيرها، وطبيعة العلاقات

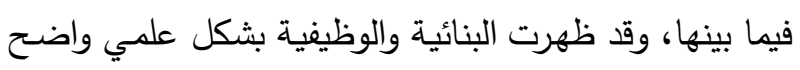


المجتمع الكبير، فالمجتمع المحلي يمنح الأسرة هويتها و وبين المتغيرات الديموجرافية، الاجتماعية، والاقتصادية

المستقلة المدروسة ".

منطقة البحث:

تم إجراء البحث الميداني بقرية صنافير التابعة لمركز

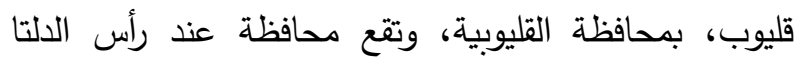
بمنطقة شرق النيل بمساحة إجمالية تقدر بنحو ا ... كم

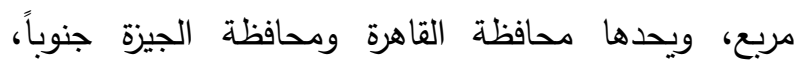
ومحافظتا الدقهلية والغربية شمالاً، ومحافظة الشرقية من جهة وهاه الشرق، ومحافظة المنوفية من جهة الغرب، وتقع المحافظة ضمن إقليم "القاهرة الكبرى"، حيث تتكون من 9 وحدات محلية، بالإضافة إلى 7 ـ 190 وحدة محلية ريفية، ويتبعها قرية، ويضم مركز قليوب: 1 مدينة, 7 قرى مركزية وهي: صنافير، بلقس، ناي، ميت حلفا، سنديون، وطنان، و وأيضاً V قرية تابعة (التوصيف البيئي لمحافظة القليوبية، V V . V Y

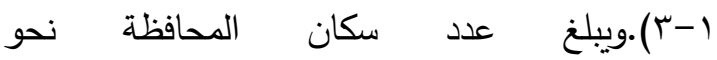

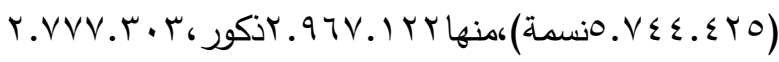
إناث، ويبلغ عدد سكان الريف بها

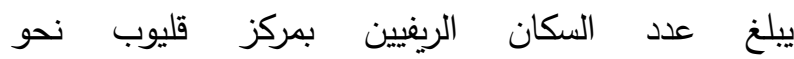

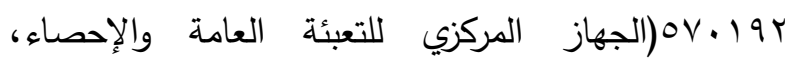
1 ا.ץ: ^ץ). وقد تم اختيار قرية صنافير التابعة لمركز

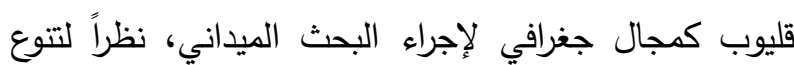
مواردها البيئية، وتمثل الزراعة بها أحد أهم أنشطتها الاقتصادية، ويبلغ عدد سكانها حوالي .. . بس نسمة، كما تبعد قرية صنافير عن مركز قليوب بما يقرب من 9 كم، وعن القاهرة بحوالي ^^ كم (مركز المعلومات بالوحدة

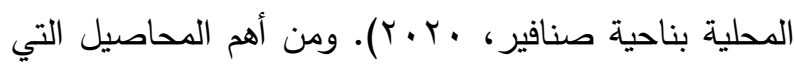
تشتهر بها القهح، الأرز، البصل، البرسيم، والبطاطس، في

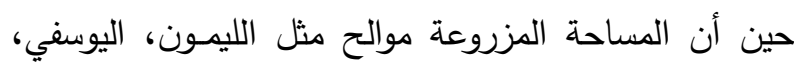
والبرتقال تقل عن · ع فدان (الجمعية التعاونية الزراعية بقرية

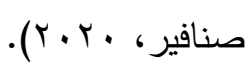

كيانها، كما يقوي روابط التماسك داخل الأسرة. ء. . المحافظة على بقاء النمط: قد يعاني الفرد من صراع الدور ، والأسرة هنا مسئولة عن امتصـاص أي توتر من

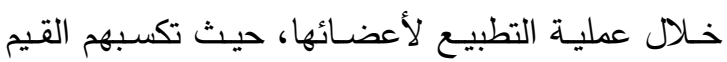

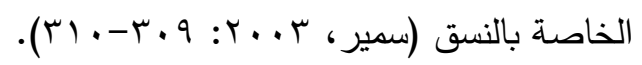
ونستخلص من العرض السـابق أن هذه النظريـة ترتكز حول بقاء النسق واستمراره، وأن كل جزء في النسق له وظيفة ودور محدد، يتكامل مع باقي أدوار ووظائف الأجزاء الأخرى

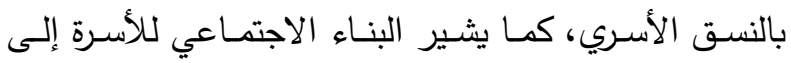

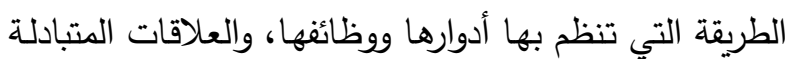
بين أجزائها، وترتكز أهم الوظائف التي تقوم بها الأسرة حول

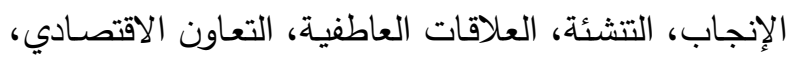

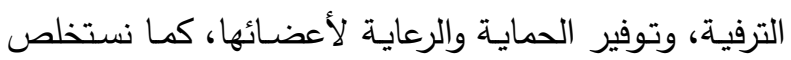

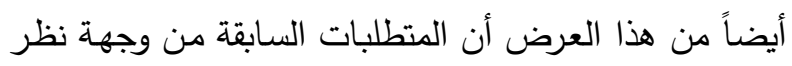

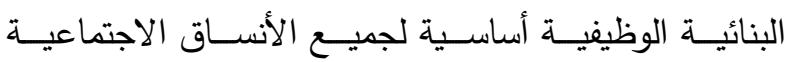
والاقتصادية الأخرى، وعلى رأسها الأسرة، والفشل في إنجازها

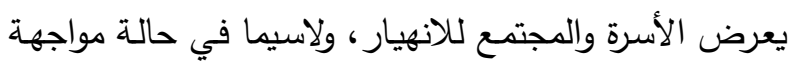

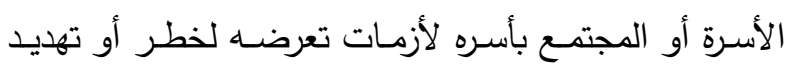

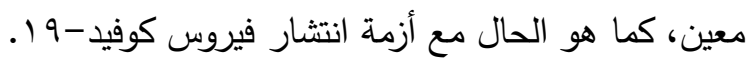

\section{الطربقة البحثية}

\section{الفرض البحثي والإحصائي:}

لكي نحقق الهدف الثاني من البحث تم صياغة الفرض البحثي على النحو التالي: "توجد علاقة بين درجة تتفيذ الأسرة الريفية للممارسات الرشيدة لمواجهة أزمة كوفيد-9 كمتغير تابع، وبين المتغيرات الديموجرافية، الاجتماعية، والاقتصادية المستقلة المدروسة". ولاختبار صحة الفرض البحثي سابق الذكر، تم صياغة الفرض الإحصائي المقابل له، والذي ينص على: "عدم وجود علاقة بين درجة تتفيذ

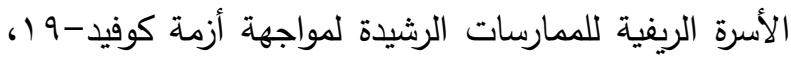


وتتكون استمارة الاستبيان من خمسة أقسام، حيث يتعلق

القسـم الأول بمقـاييس المتغيـرات الثخصـية، والقسـم الثـاني

يحتوي على مقياس لقياس متغير درجـة تتفيذ الأسرة الريفية

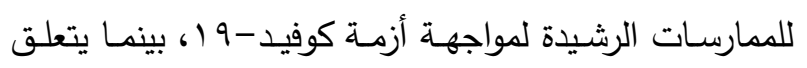
القسم الثالث بمقاييس المتغيرات الاجتماعيـة، والاقتصـادية، أما القسم الرابع فهو متعلق بمصـادر معلومات الأسرة الريفية حول فيروس كوفيد-9 (1، المعوقات التي تعاني منها الأسرة لمواجهة أزمـة كوفيد-9 (، وكذا أهم الدروس المستفادة من حون تلك الأزمـة، وأخيراً القسم الخامس والمتعلق ببيانات منطقة التهم البحث.

المعالجــة الكميــة وقيـاس المتفيـرات: فيمـا يلـي عـرض للتعريفات الإجرائية لأهم متغيرات الدراسـة، وكيفيـة قياسها، وقد تم الاسترشاد ببعض الدراسات السابقة في تتاولها لكيفية

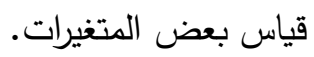

التعريف الإجرائي للمتغير التابع وطريقة قياسه: - درجة تنفيذ الأسرة الريفية للممارسـات الرشيدة لمواجهة

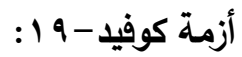

ويقصـد بها إجرائيـاً في البحث الـراهن بأنها درجـة قيـام الأسرة الريفية بمجموعة الأنثطة، الأفعال، والإجراءات، لكي يتم التعايش مـع أزمـة فيروس كورونا المستجد (كوفيد-9 ())،

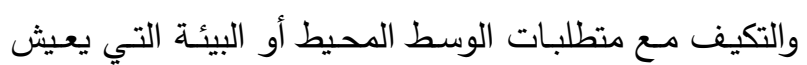
فيها الفرد والأسرة في ظل وجود هذه الأزمة، وهي ممارسات

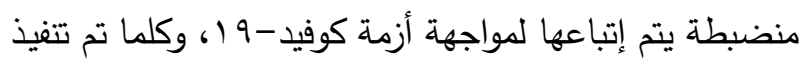
تلـك الممارسـات الرشيدة والمنضـبطة، كلمـا كانـت نتيجتهـا إيجابيـة للفرد والأسـرة، وسـرعان مـا تتحـول تلك الممارسـات لعادة تؤدي غرضها بكل يسر وتلقائية بطريقة يمكن قياسها. وقد تم قياس هذا المتغير بمقياس مكون من أربعة أقسام، ويحتوي هذا المقياس على أربعة وعشرين بند، تقيس درجة تنفيذ الأسرة الريفية للممارسات الرشيدة لمواجهة أزمـة كوفيد-

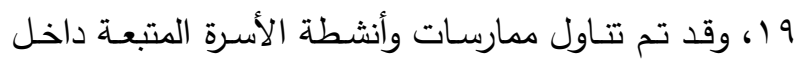
المنزل، خـارج المنزل، وفور العـودة للمنزل، بالإضـافة إلى ولى

\section{شاملة وعينة البحث:}

تتمثل شاملة البحث في جميع الأسر الريفية التي تمتلك حيازة لأرض زراعية بالجمعية التعاونية الزراعية بقرية صنافير التابعة لمركز قليوب، بمحافظة القليوبية، وقد بلغ إجمالي عددهم £191 حيازة أسرية، وقد تم تحديد حجم

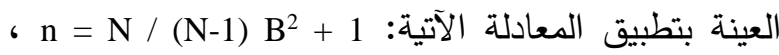
حيث أن: n = حجم العينة، N = حجم الثاملة، $\mathrm{n}$ = خطأ

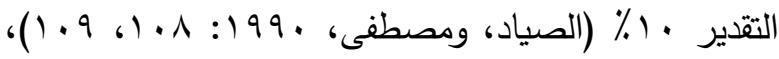
وقد بلغ حجم العينة نحو ؟0, 9، وتم تقريبها ليصبح حجم العينة و 9 أسرة ذات حيازة زراعية، وقد تم سحبها بطريقة

عشوائية بسيطة.

نوع الدراسة والمنهج المستخدم:

تعتبر الدراسـة الراهنـة مـن الدراسـات الوصفية التحليلية، حيث تستهدف قياس مستوى تتفيذ الأسرة الريفية للممارسات الرشيدة لمواجهة أزمة كوفيد-9 (، كما تستهدف التعرف على

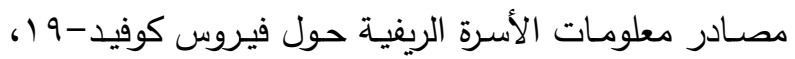
وكذا التعرف على المعوقات التي تعاني منها الأسرة الريغية لمواجهة أزمة كوفيد-9 (، فضلاً عن اختبار بعض الفروض

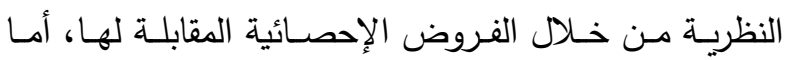
المـنهج المسـتخدم في الدراســة الراهنـة فهـو مـنهج المســح

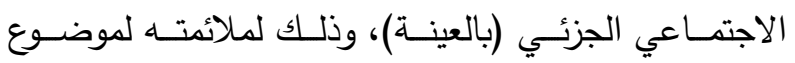
الدراسة. طريقة وأداة جمع البيانات:

تم إجراء الاختبار القبلي Pre-Test لاستمارة الاستبيان على ع ا مبحوث بقربـة سنديون التابعـة لمركز قليوب بالقليوبية،

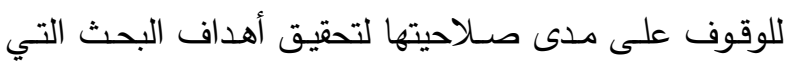
صـمدت مـن أجلهـا، وقـد تـم إجـراء البحـث الميداني بقريـة صنافير التابعة لمركز قليوب، بمحافظة القليوبية، من خلال المقابلـة الشخصية لأرباب الأسـر الريفيـة التي تمتلك حيازة زراعية باستخدام استمارة استبيان، وذلك خلال شهر أغسطس

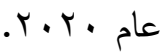




$$
\text { مجلة الإسكندرية للتبادل العلمى - (مجلد بـ العدد () يناير - مارس (Y.r }
$$

- درجة التماسك الأسسري: ويعني مدى الترابط بين الوالدين وأفراد الأسرة، وتم قياسـه بمجموعة بنود، وأعطيت الدرجات

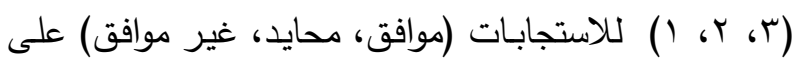
التوالي.

- درجة التوافق بين الزوجين: أي مدى التفاهم بين الزوجين

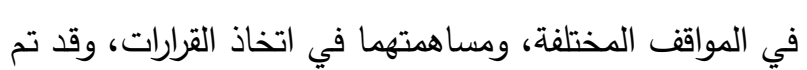

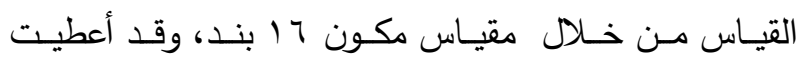

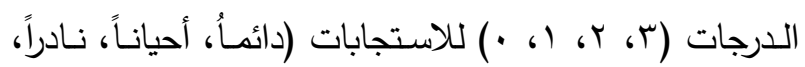
لا لا على الترتيب. - درجـة التعـرض لوســائل التواصـل الجمـاهيري: أي درجـة استخدام وسائل الإعلام التقليدية سواءً المقروءة أو المسموعة

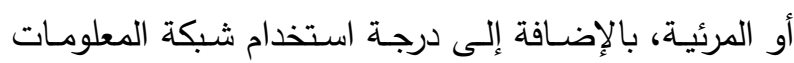
الإلكترونية، وتم قياسه بمقياس مكون من · ل بنود، وأعطيت

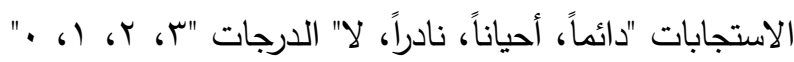

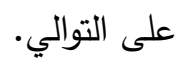

- الاسـتراتيجيات الخاصـة بالأسـرة: ويقصــ بها الإجـراءات التي تتبعها الأسرة للتكيف مع ظروف الحياة، بهدف معرفة الإجراء الذي زاد أو قل اللجوء إليه، وتم قياسه من خلال .

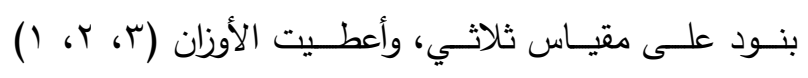
الاستجابات (زادت، لم تتغير، قلت) علي التوالي.

- طرق عـلاج أفراد الأسـرة: ويقدر برقم تجميعي ناتج عن جمـع الـرجات التي تعطى لكل طريقـة مـن طـرق العـلاج، والتي تم تحديدها في خمس طرق بدءاً من العـلاج بالطرق الشعبية وانتهاءً بالكشف عند دكتور متخصص، وتم قياسـه من خـلال مقيـاس مكون من أربع درجات: (دائهـاً، أحيانـاً،

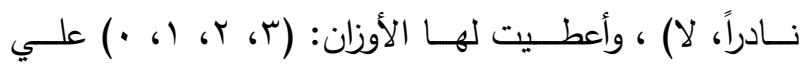
الترتيب.

- درجة المشاركة الاجتماعية غير الرسمية: أي تحديد درجة

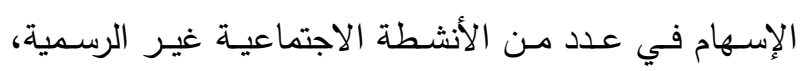

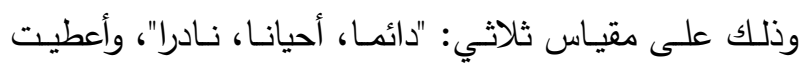

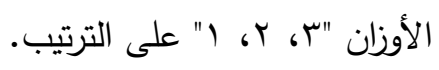

الممارسـات والأنشطة المتبعـة لضـمان سـلامة الأغذيـة، وقد اشتمل كل قسم من هذه الأقسام الأربعة على ستة بنود، وذلك من خـلال مقيـاس ثلاثي يضـم ثلاث درجـات : (ينفذ دائمـا،

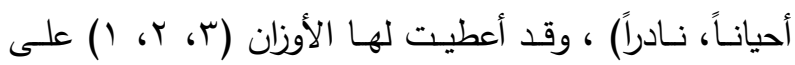

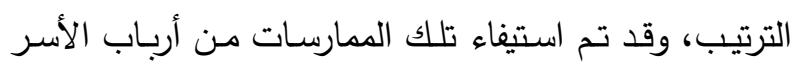

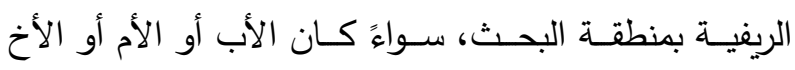
الأكبر ، وذلك لكونهم هم المسئولين عن الأسـرة، ولإلمـامهم بكل شئون الأسـرة وأفرادهـا، وبـالأخص في ظل وجود ودئ أزمـة

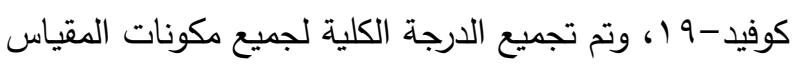

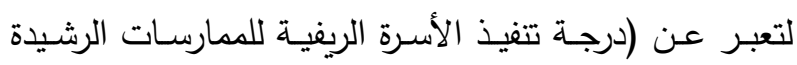

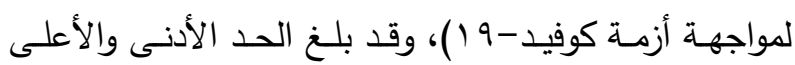

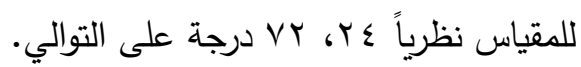
المتغيرات المستقلة: - العمـر : ويقصــ بـه العمـر الحسالي للمبحوث مقاسـاً بعدد السنوات الخام وقت إجراء البحث الميداني. - عدد سنوات التعليم الرسـي: ويقصد بـه إجمالي سنوات تعليم المبحوث، وتم تقديرها بالرقم الخام. - الحالــة الزواجيـة: ويقصــ بهـا الحالـة الزواجيـة للمبحوث

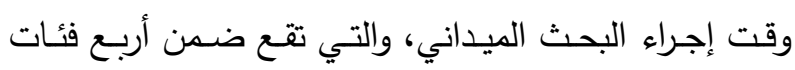

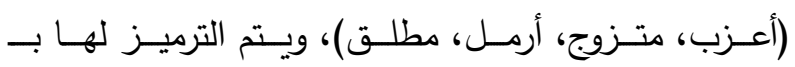

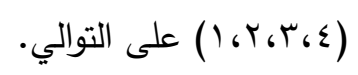

- عدد أفراد الأسـرة: وتم قياسـهـ بحصـر جميـع أفراد أسرة المبحوث وقت إجراء البحث الميداني. - الحالــة المهنيــة: أي وظيفــة المبحـوث الرئيسـية، وتـم حصرها في (مزارع، موظف حكومة، موظف قطاع خاص،

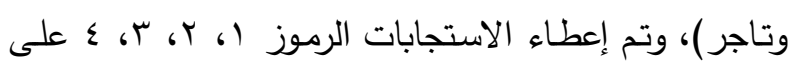

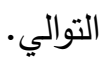

- عدد الأفراد المتعطلين عن العمـل بالأسـرة: ويقصد بها

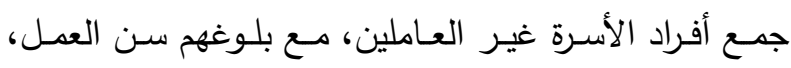
وتوافر القدرة والرغبة والبحث عن العمل، وتم قياسـه وتقديره

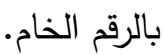


- درجة انتثار الفقر بالقرية: أي درجة معاناة سكان القرية

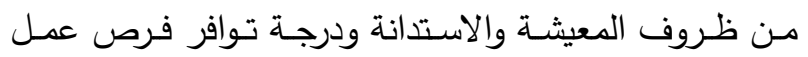

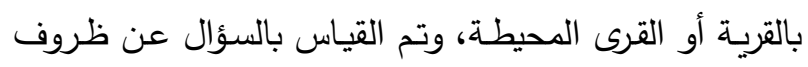

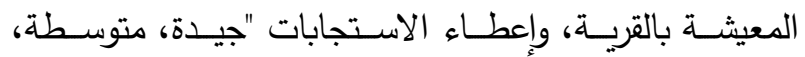

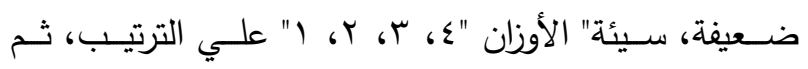

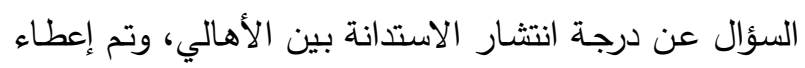

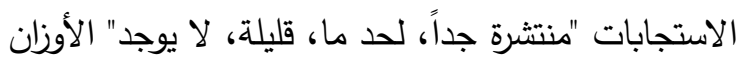

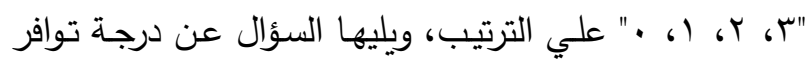

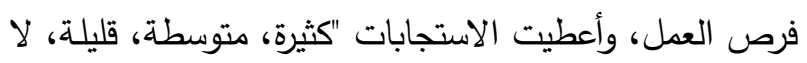

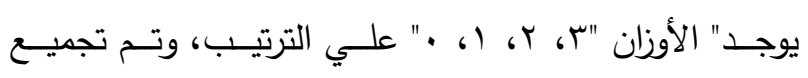
الدرجة الكلية لتعبر عن هذا المتغير. أدوات التحليل الإحصائي:

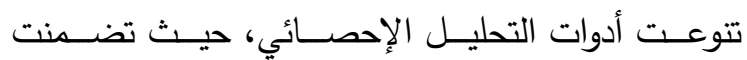
استخدام النسب المئوية والتكرارات، مقاييس التشتت، مقاييس

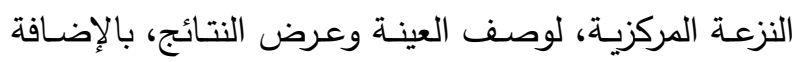
Pearson Product إلى استخدام معامل الارتباط البسيط Chi Square Correlation Coefficient وذلك لاختبار معنوية العلاقات بين المتغير التابع والمتغيرات

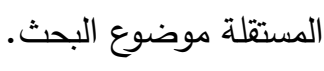

\section{وصف عينة البحث}

تثــير البيانـات الــواردة بجــول ( () إلـى توزيــع

المبحوثين حسب خصائصهـم الشخصية، حيث تبلـخ نسبة

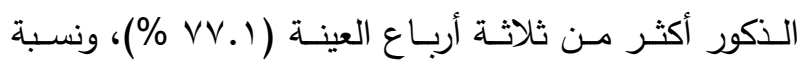

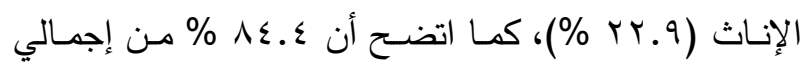

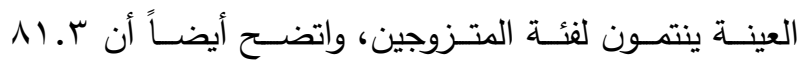
يعملون بمهنة الزراعة، كما بلغت نسبة الأسر البسيطة بالعينة

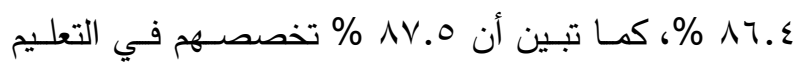

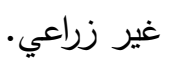

- درجة الاتجاه نحو المحافظة على البيئة: ويقصد به درجة الاستعداد نحو المحافظة على موارد البيئة، وتم قياس هذا المتغير من خـلال استيفاء الآراء حول · ل عبارات بعضهـا إيجـابي والآخر سلبي، تدور حـول المعـارف والممارسـات

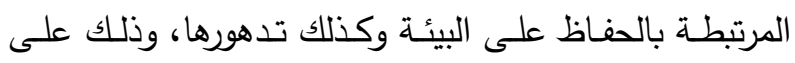

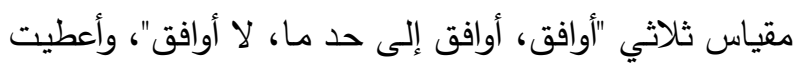
الأوزان "اك، ז، ا" على الترتيب.

- الاخل الثهري للأسرة: أي إجمالي دخل أسرة المبحوث من الهن كل المهن، وتم قياسه بالجنيه الدصري شهرياً. - إجمالي الإنفاق الثـهري للأسرة: أي كل ما تنفقه الأسرة

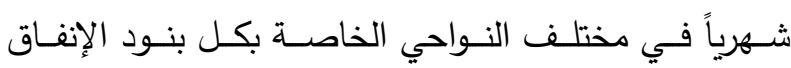
والتكاليف لدي الأسرة، وتم قياسه بالجنيه المصري شهرياً.

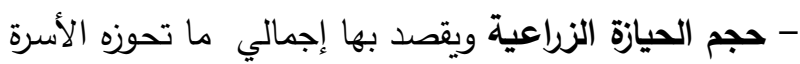
من أرض زراعية، وتم القياس بسؤال المبحوثين عن مساحة الأرض الزراعية التي تقع في حيازته (إيجار أو ملك)، مقدرة

بالقيراط. - (الارض.

- حيـازة الآلات الزراعيـة: أي عدد مـا تحـوزه الأسـرة مـن

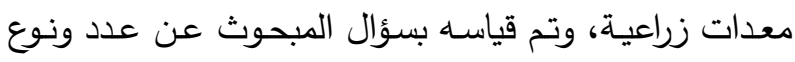

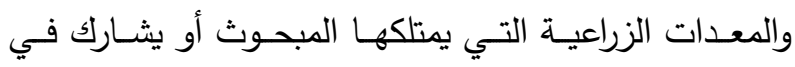
ملكيتها، وذلك بعد إجراء عملية التحويل للدرجات المعياريـة وفقاً لمعايير معهد بحوث الميكنة الزراعية.

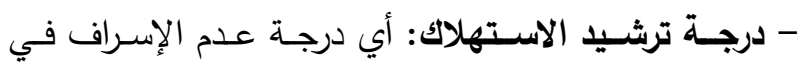

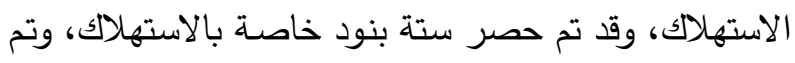
القياس بسؤال المبحوث عن كل بنود الاستهلاك الستة، وذلك

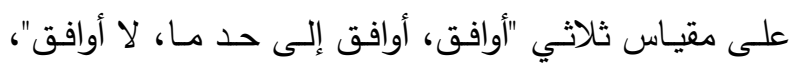

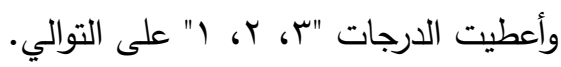

- نصيب الفرد من حجم الحيازة الزراعية للأسرة : أي نصيب

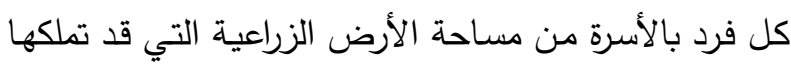

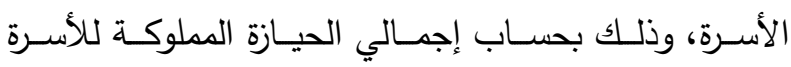
بالقيراط، وقسمتها على أفراد الأسرة، مـع مراعاة مـا يقتضيه نصيب الفرد في حالة إذا ما كان ذكر أو أنثي. 
r، 11 كحد أدنى وأعلى على الترتيب، بمتوسط حسابي

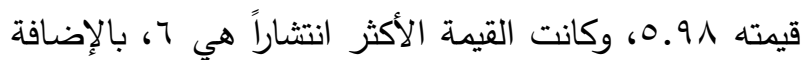

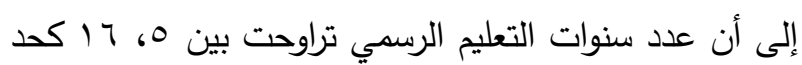
أدنى وأعلى على الترتيب، بمتوسط حسابي بلغت قيمته

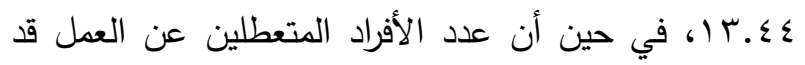

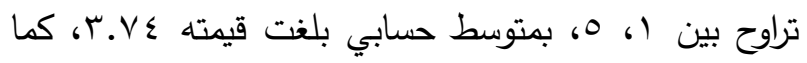

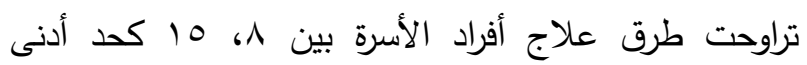

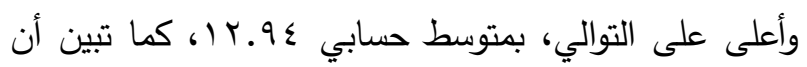
درجة المشاركة الاجتماعية غير الرسمية تتراوح بين 9 ، 17

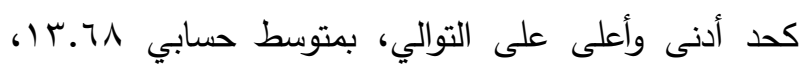
بينما تبين أن درجة الاتجاه نحو المحافظة على البيئة تتراوح

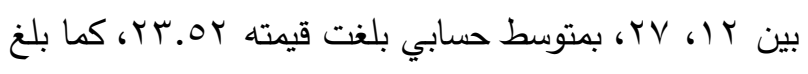

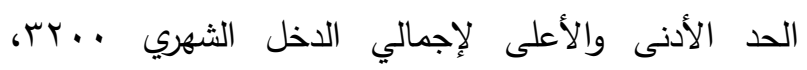

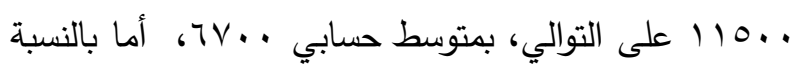

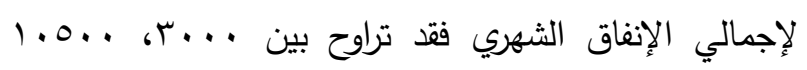

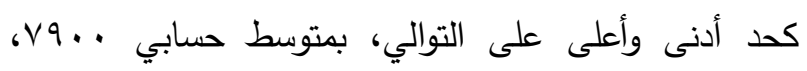

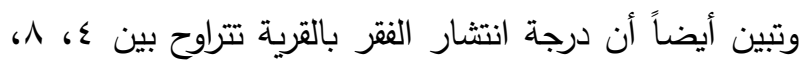
بمتوسط حسابي ب. ب. ، أما درجة ترشيد الاستهلاك للأسرة فقد تراوحت بين 9، 17 كحد أدنى وأعلى على الترتيب، بمتوسط حسابي بلغت قيمته نحو ع ـ11 11 .
جدول ا . توزيع المبحوثين وفقاً لخصائصهم الثخصية ذات مستوي القياس الوصفي (ن

\begin{tabular}{|c|c|c|c|}
\hline$\%$ & العدد & الفئات & خصائص المبحوثين \\
\hline$V V .1$ & $V \varepsilon$ & - - ذكر & \\
\hline rr.q & r & - & النوع \\
\hline$\wedge \varepsilon . \varepsilon$ & 人) & - متزوج - مت & \\
\hline $0 . r$ & 0 & 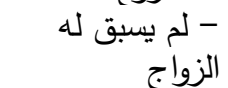 & - الحالة الزواجية \\
\hline r.l & r & - مطلق & \\
\hline V.r & $\checkmark$ & - أرمل & \\
\hline N1.r & $\vee \wedge$ & - - مزارع & \\
\hline$\Lambda . r$ & $\wedge$ & - ت - تاجر & - الحالة المهنية \\
\hline T.Y & 7 & - موظف حكومى & \\
\hline$\varepsilon . r$ & $\varepsilon$ & - بالقطاع خاص & \\
\hline 人५. & $\Lambda r$ & - بسيطة - بسية & \\
\hline$\varepsilon . Y$ & $\varepsilon$ & - - مركبة & - نوع الأسرة \\
\hline $9 . \varepsilon$ & 9 & - ممتدة & \\
\hline Ir.O & ir & - زراعى - ز & - نوع التخص \\
\hline Vฯ.. & $v r$ & - غير زراعي & * التعليم \\
\hline
\end{tabular}

ويتضح من البيانات الواردة بجدول (Y) أن عمر

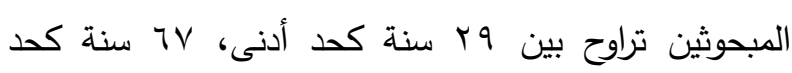

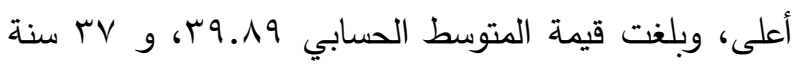
هو العمر الأكثر انتشاراً بالعينة، كما تراوح حجم الأسرة بين

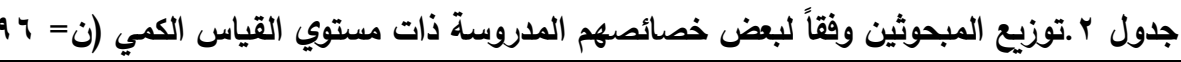

\begin{tabular}{|c|c|c|c|c|c|}
\hline المنوال/القيمراً التثشارً & الانحراف & الحتوسطى & أعلى قيمة & أدنى قيمة & ذات مستوي القياس المبحثين الكمى \\
\hline$r v$ & $V . r \leq$ & $r 9.19$ & TV & rq & III \\
\hline 7 & r. & 0.91 & 11 & r & - عدد أفراد الأسرة \\
\hline 9 & T.VT & $1 T . \varepsilon \varepsilon$ & 17 & 。 & - عدد سنوات التعليم الرسمى \\
\hline r & 1.174 & $T . V \varepsilon$ & o & 1 & - عدد الأفراد المتعطلين عن العمل بالأسرة \\
\hline 11 & r.人т & $1 Y .9 \varepsilon$ & 10 & $\wedge$ & - طرق علاج أفراد الأسرة \\
\hline ir & «.11 & $1 \pi .71$ & 17 & 9 & - درجة المشآركة الاجتماعية غير الرسمية \\
\hline rt & $7 . Y 7$ & rr.or & rV & it & - درجة الاتجاه نحو المحافظة على البيئة \\
\hline 1. & T.VV & Ir..A & $1 \leq$ & $\checkmark$ & - الاستراتيجيات الخاصة بالأسرة الريفية \\
\hline ro.. & $1 \leq 9$. & $7 \vee \ldots$ & $110 \ldots$ & r... & - إجمالى الدخل الثهري للأسرة \\
\hline $00 \ldots$ & ITE. & $\vee \vee \ldots$ & $1.0 \ldots$ & $r \ldots$ & - إجمالى الإنفاق الشهري للأسرة \\
\hline 0 & r.17 & $0 . \wedge r$ & $\wedge$ & $\varepsilon$ & - درجة انتشار الفقر بالقرية. \\
\hline 11 & r.. & $11.7 \varepsilon$ & 17 & 9 & رشيد الاستهلاك لتلأسرة \\
\hline
\end{tabular}

- المصدر : جمعت وحسبت من بيانات البحث. 


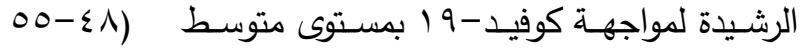

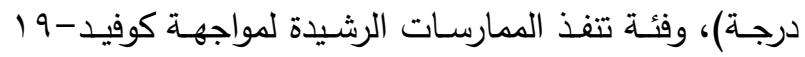
بمستوى مرتفع (00 درجة فأكثر)، وقد بلغت نسبة الأسر التي

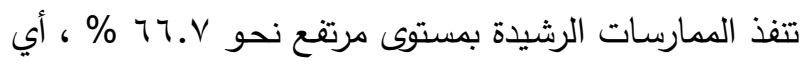

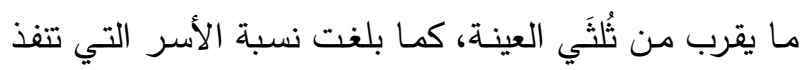

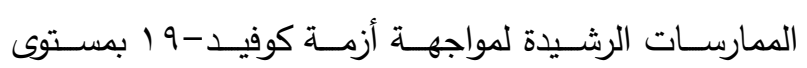
مـنخفض نحـو 19.1 \% \%، أي مـا يقرب مـن خمس العينـة، بينما بلغت نسبة الأسر التي تتفذ الممارسات الرشيدة بمستوى

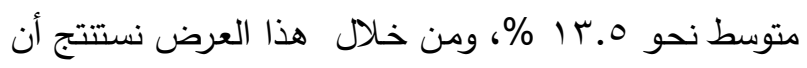

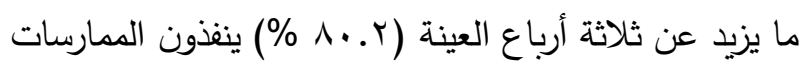
الرشيدة لمواجهة أزمة كوفيد-9 ( بمستوى (متوسط ومرتفع)، وقد يرجع ذلك إلى لسببين رئيسين، السبب الأول مؤداه أنها مسألة حياة أو موت، فأغلب من أصيبوا بالفيروس قد وافتهم

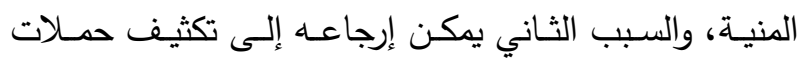

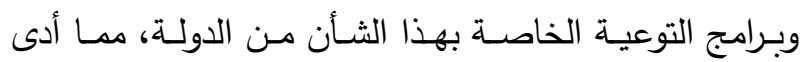
لزيـادة وعى الأفراد والأسر في المجتمع المصري ككل، وفي المجتمع الريفي على وجه الخصوص.

\section{النتائج ومناقشتها}

أولاًا- مستوى تنفيذ الأسرة الريفية للممارسات الرشيدة لمواجهة أزمة كوفيد-9 المسويد

يتبين من النتائج الواردة بجدول (r) توزيـع المبحوثين طبقـاً لمعـالم المتغيـر التـابع (مسـتوى تتفيـذ الأسـرة الريفيـة للممارسات الرشيدة لمواجهة أزمـة كوفيد-9 ( )، فقد تراوحت

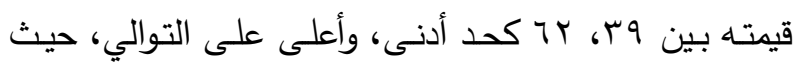
بلغت قيمـة المـى سب، بمتوسط حسـي بلغـت قيمتهـ نحو

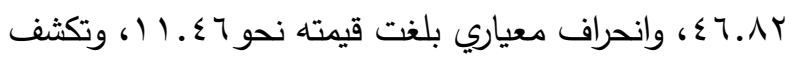
قيم الحد الأدنى، الأعلى، والمدى عن وجود تباين وتفاوت في مستوى تتفيذ الممارسات الرشيدة بين الأسر الريفية، والتي من شأنها مواجهة أزمة كوفيد-9 1.

تم تقسيم المبحوثين حسب المـدى الفعلي لدرجـة تتفيذ أسرهم الريفيـة للممارسـات الرشيدة لمواجهة أزمـة كوفيد-9 19

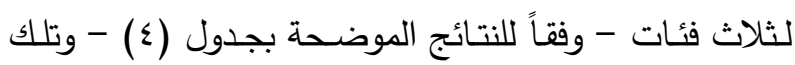
الفئات هي: فئة تنفذ الممارسات الرشيدة لمواجهة كوفيد9 (بمستوى منخفض (V) درجة فأقل)، فئة تتفذ الممارسات

جدول ب. توزيع المبحوثين وفقاً لمعالم المتغير التابع: (درجة تنفيذ الأسرة الريفية للممارسات الرشيدة لمواجهة أزمة كوفيد-9 (1)

\begin{tabular}{|c|c|c|c|c|c|}
\hline الانعراف & الحستابى & المدى & أعلى قيمة & أدنى قيمة & معالم المتغير التابع \\
\hline $11 . \varepsilon 7$ & $\Sigma \neg . \wedge r$ & $r T$ & Tr & $r q$ & - مستوى التعدي على الأرض الزراعية بالبناء \\
\hline
\end{tabular}

جدول ؛ . توزيع المبحوثين وفقاً لمستوى تنفيذ أسرهم للممارسات الرشيدة لمواجهة أزمة كوفيد-9 19 (ن ج 9)

\begin{tabular}{|c|c|c|}
\hline$\%$ & 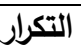 & الفئــات \\
\hline 19.1 & 19 & مستوى منخفض ( V؛ درجة فأقل). \\
\hline $1 \% .0$ & it & مستوى متوسط (^ ؛ - هـ درجة). \\
\hline 74.8 & $\uparrow \xi$ & مستوى مرتفع (ه ه درجة فأكثر). \\
\hline $1 \ldots$ & 97 & 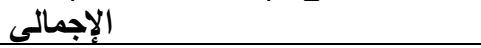 \\
\hline
\end{tabular}


للممارسـات الرشيدة لمواجهة أزمـة كوفيد-9 1 مرهون بزيـادة

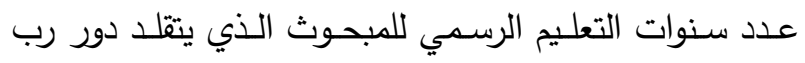
الأسرة، وتلك النتيجة تحمل في طياتها منطق مؤداه أن ارتقاء المبحوث في التعليم يجعله قادراً على التأثير في أسرته لما فيا يملكه من وعي وقدرة على الإقناع بإتباع الممارسات الرشيدة

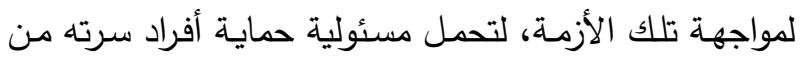
خطورة هذا الفيروس المنتشر .

وتبين أيضاً من النتائج الموضحة بجدول (0) عدم وجود

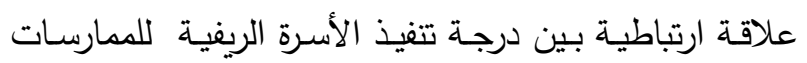

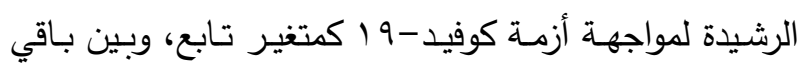
المتغيـرات الديموجرافيـة، لـذا يمكـن رفضض الفـرض البحثي لرفي البديل، ولا يمكن رفض الفرض الإحصائي الذي ينص على

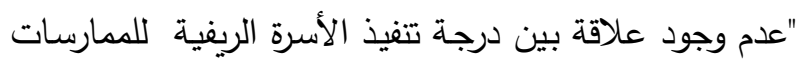
الرشيدة لمواجهة أزمة كوفيد-9 ا كمتغير تابع، وبين كل من:

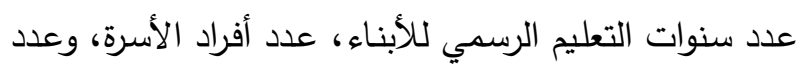
الأفراد المتعطلين عن العمل بالأسرة".

كـــا تشــير النتـائج الــواردة بجــدول (0)، والمتعلقـة بـالمتغيرات الاجتماعيـة لوجـود علاقـة ارتباطيـة موجبـة بـين

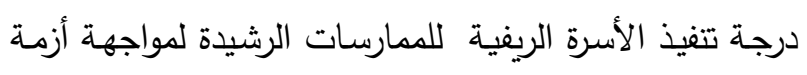
كوفيد-9 1 وبين متغيري: (درجة التعرض لوسائل التواصل

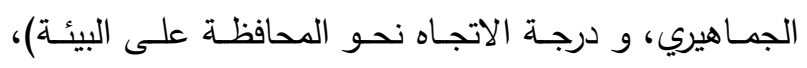

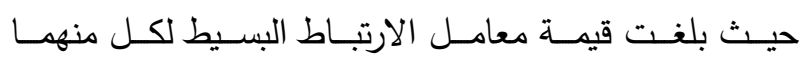

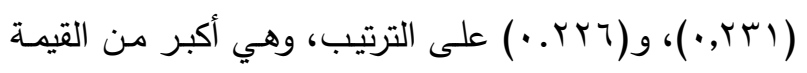

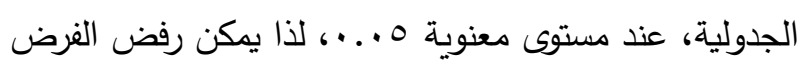
الإحصـائي، ولا يمكن رفض الفرض البحثي البديل الخاص معضدونه

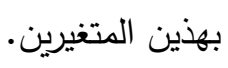
وبالنسبة للنتيجة المتعلقة بمتغير درجة التعرض لوسائل

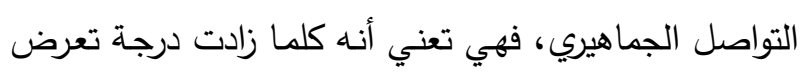

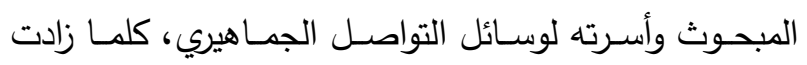

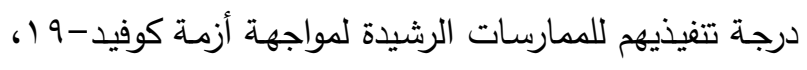

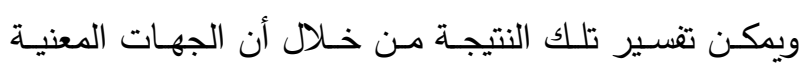

ثانيـاً- طبيعـة العلاقـة بـين درجـة تنفيـذ الأسـرة الريفيـة للممارسـات الرشيدة لمواجهة أزمـة كوفيـ-9 19 والمتغيـرات المستقلة المدروسة:

أ- اختبـار وجـود علاقـة معنويـة بـين درجـة تنفيــ الأسـرة الريفيـة للممارسـات الرشيدة لمواجهـة أزمـة كوفيــ- 19 كمتغير تابع، وبين المتغيرات المستقلة الكمية المدروسـة باستخدام معامل الارتباط البسيط:

تم اختبار معنويـة العلاقة بين درجة تنفيذ الأسرة الريغية

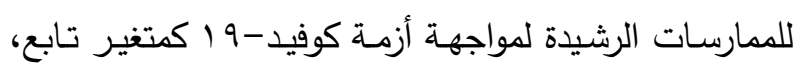
وبين المتغيرات الكمية المستقلة المدروسـة، والتي بلغ عددها

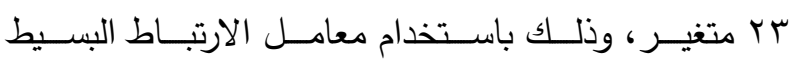
"لبيرسون"، بالنسبة للمتغيرات الديموجرافية قد تبين من النتائج الواردة بجدول (0)، وجود علاقة ارتباطية موجبة بين درجة

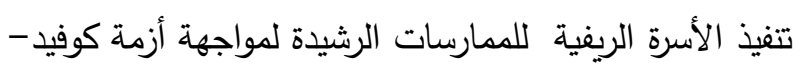

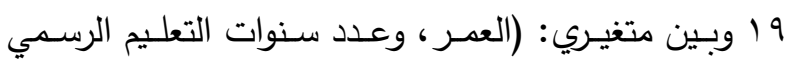
للمبحوث)، وقد بلغت قيمة معامل الارتباط البسيط لكل منهما

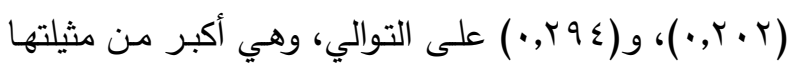

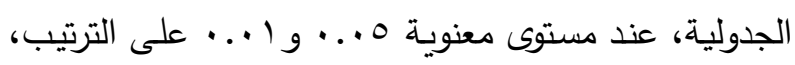

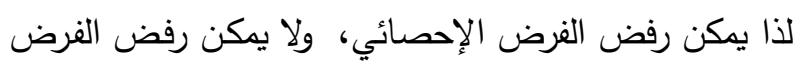
البحثي البديل المتعلق بهذين المتغيرين. وبالنسبة للنتيجة المتعلقة بمتغير العمر، فهي تعني أنه به بهائ كلما زاد عمر المبحوث، والذي يمثل رب الأسرة، كلما زادت

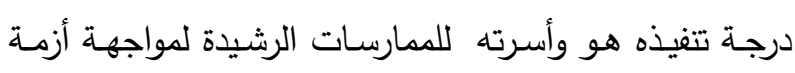
كوفيد-9 (، وقد يرجع السبب في ذلك إلى أن الفرد قد يزداد

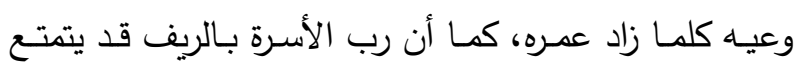

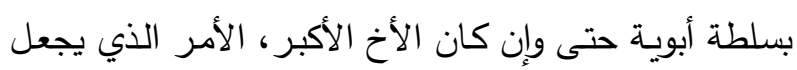
منه قدوة ذو رأي مسموع ويُنَفَ، فضلاً عن حرص رب الَ الأسرة

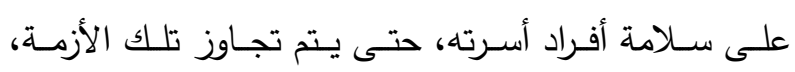
وبالنسبة للنتيجة المتعلقة بمتغير عدد سنوات التعليم الرسمي للمبحـوث، فهى تعنـي أن ارتفـاع درجـة تتفيذ الأسـرة الريفيـة 
وبالنسبة للمتغيـرات الاقتصـادية فقد تبين وجـود علاقـة ارتباطية موجبة بين درجـة تنفيذ الأسرة الريفيـة للممارسـات

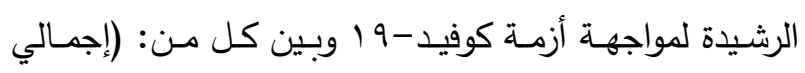
الإنفــاق الثــهري، حجـم الحيـازة الزراعيـة، و درجـة ترشـيد الاستهلاك)، حيث بلغـت قيم معامل الارتباط البسيط لكل

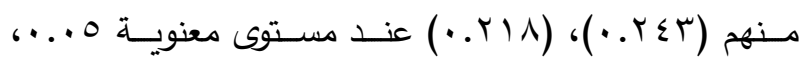

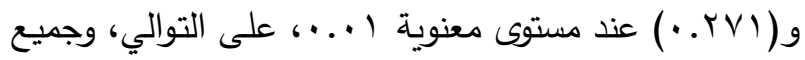

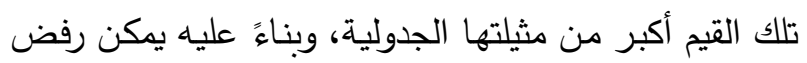
الفرض الإحصـائي، ولا يمكن رفض الفرض البحثي البديل، المتعلق بتلك المتغيرات. وفيمـا يتعلق بالنتيجـة الخاصـة بمتغيـر إجمـالي الإنفـاق

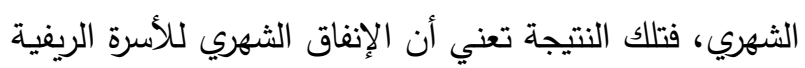

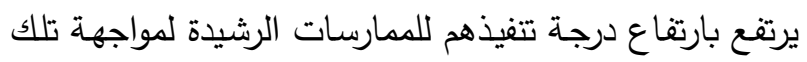

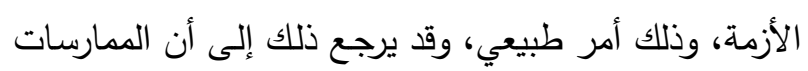

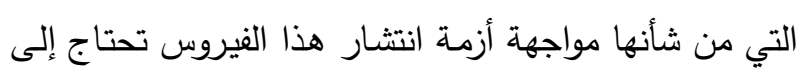

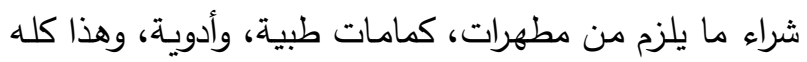
سوف يرفع من تكاليف الإنفاق الكلي للأسرة الريفية، في حين

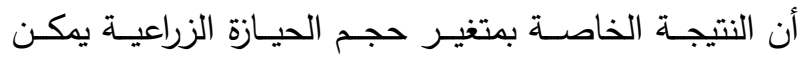

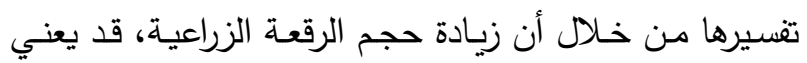
ارتفاع دخل الأسرة الريفية العائد من الأرض الزراعيـة التي تقع في حوزتها، الأمر الذي قد يمكن الأسرة مادياً من تحمل الأرل تكاليف تتفيذها للممارسـات التي من شـأنها مواجهة كوفيد-

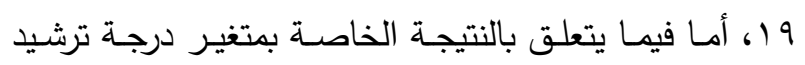

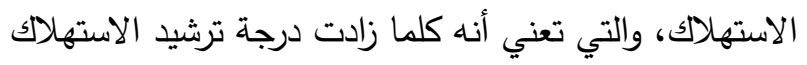

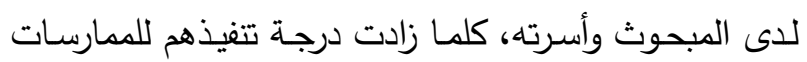

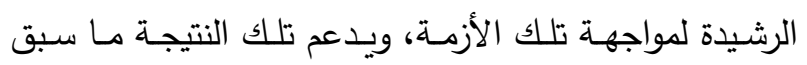
عرضــه من نتائج، حيث أن الأسـرة التي تتسـم بالترشيد في

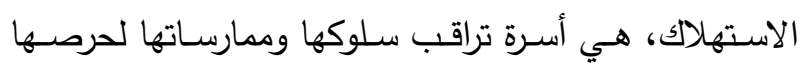
على الترشيد، وهذا يزيد من توقع قيامها بتتفيذ كل الممارسات

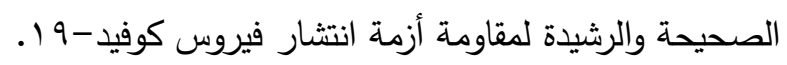
كما تشـير النتائج المبينـة بجدول (0) إلى عدم وجود
كرئاسـة الـوزراء، ووزارة الصـحة والسـكان أصسبحت تخاطبب

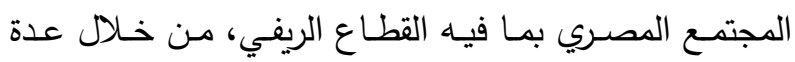
وسائل، من أهمها مواقع وسائل التواصل الاجتماعي، فضـلاً عن الصـحف الوطنيـة والقنـوات الفضـائية، حيث تم توجيـه برامج عديدة لتثقيف وتوعية الجماهير بخصوص تلك الأزمة، وأصبحت كل الجهات المعنية حريصـة على أن تتشر كيفية التعامل مع تلك الأزمة، ومراعاة تتفيذ الاحتياطات اللازمة، بإتباع الممارسـات الرشيدة والصـحيحة، والتي من شـانها أن تقي الأفراد والأسر من الإصابة بهذا الفيروس، بالإضافة إلى ليى الإجراءات المتبعة في حالة الإصـابة بهذا الفيروس، لذا فقد أصسبح التعـرض تلـك الوســائل يـدعم تتفيـذ أفـراد الأسـرة

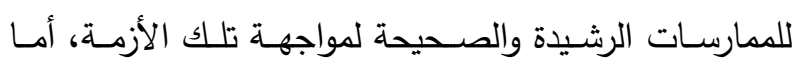
بالنسبة للنتيجة الخاصـة بمتغير درجة الاتجاه نحو المحافظة على البيئة، والتي تعني أنه كلما زادت درجة اتجاه المبحوث وأسرته نحو المحافظة على البيئة، كلما زادت درجـة تتفيذهم للممارسات الرشيدة لمواجهة تلك الأزمة، وتعتبر تلك النتيجة منطقية، حيث أن الفرد الذي لديه استعداد وميل نحو الحفاظ على البيئة، سيكون من المتوقع أن إتباعه لإجراءات الوقاية

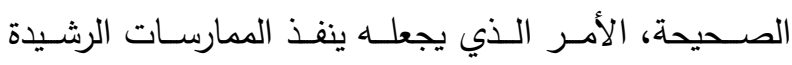
والصحيحة لمواجهة أزمـة كوفيد-9 ا، وتجنب أي ممارسات خاطئة قد تؤدي إلى العدوى بهذا الفيروس. كما اتضـح عدم وجود علاقة ارتباطية بين درجـة تتفيذ

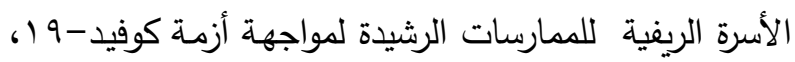
وباقي المتغيرات الاجتماعية، لذا يمكن رفض الفرض البحثي البديل، ولا يمكن رفض الفرض الإحصائي الذي ينص على

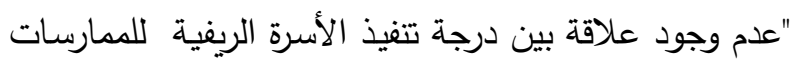

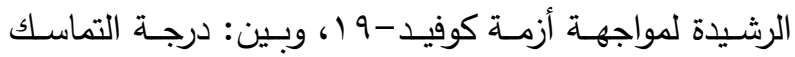
الأســري، درجــة التوافـق بـين الـزوجين، درجــة الانفتــاح

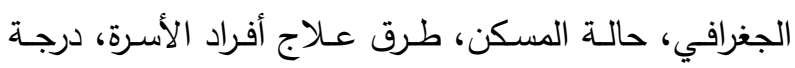
المشاركة الاجتماعية غير الرسمية، والاستراتيجيات الخاصـة

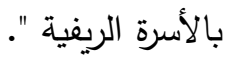




$$
\text { مجلة الإسكندرية للتبادل العلمى - (مجلد بع العدد () يناير - مارس اY.r }
$$

كمتغيـر تــابع، وبـين المتغيـرات المسـتقلة الوصـفية

\section{المدروسة باستخدام اختبار مربع كاي:}

تم تطبيق اختبار مربع كاي بغرض الكثف عن معنوية العلاقة بين فئات مستوى تتفيذ الأسرة الريفية للممارسات

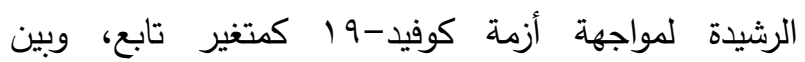
المتغيرات المستقلة الوصفية المدروسة، وهي: (النوع، نوع التخصص في التعليم، نوع الأسرة، الحالة المهنية، والحالة الزواجية). وتوضح النتائج التي وردت بجدول (†) أنه عند

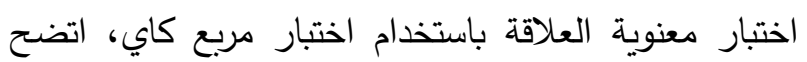
أنها معنوية عند مستوى 0...، بين مستوى الهو تتفيذ الأسرة الريفية للممارسات الرشيدة لمواجهة أزمة كوفيد-9 1 كمتغير تابع، ونوع التخصص في التعليم، فقد بلغت قيمة كا2

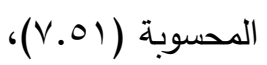

علاقة ارتباطية بين درجـة تنفيذ الأسـرة الريفيـة للممارسـات الرشيدة لمواجهة أزمـة كوفيد-9 ا كمتغير تابع، وبين باقي المتغيـرات الاقتصـادية، لـذا يمكن رفض الفـرض البحثي البديل، ولا يمكن رفض الفرض الإحصائي الذي ينص على "عدم وجود علاقة بين درجة تتفيذ الأسرة الريفية للممارسات

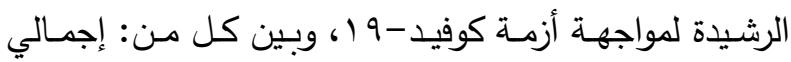
الــخل الثــري، حجـم الحيـازة الحيوانيـة، ملكيــة الأجهـزة المنزلية، درجة انتثـار الفقر بالقربـة، نصيب الفرد من حجم

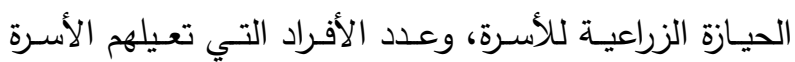
اقتصادياً.

ب- اختبار وجود علاقة معنويـة بين مستوى تنفيذ الأسرة الريفية للممارسات الرشيدة لمواجهة أزمـة كوفيد- 19

جدول ه. نتائج اختبار معامل الارتباط البسيط لبيرسون لتحديد معنوية العلاقة بين درجة تنفيذ الأسرة الريفية للممارسات الرشيدة

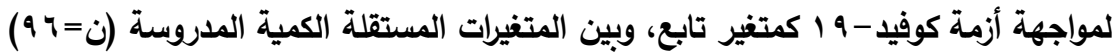

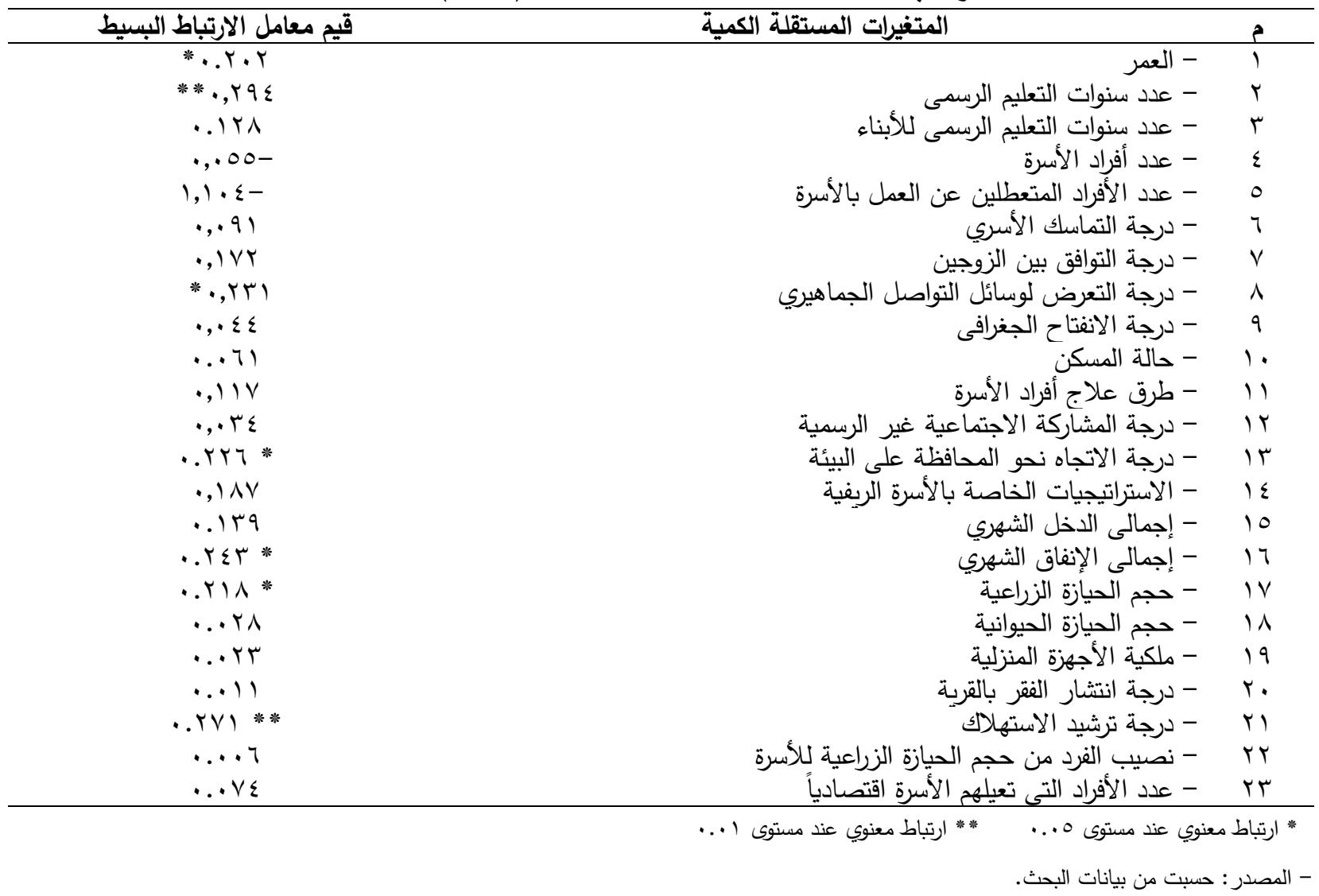


جدولף نتائج اختبار مربع كاي (كا2) لتحديد معنوية العلاقة بين مستوى تنفيذ الأسرة الريفية للممارسات الرشيدة لمواجهة أزمة كوفيد-

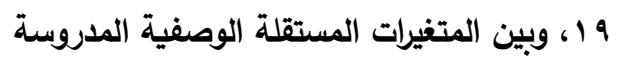

\begin{tabular}{|c|c|c|c|c|}
\hline درجات الحربة (df) & قيمة (كا2) الجدولية * & قيمة (كا2) المحسوبة & المتغيرات المدروسة & 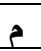 \\
\hline$r$ & 0.99 &.$\wedge V$ & - النوع - & 1 \\
\hline r & 0.99 & $\vee .01 *$ & - نوع التخصص فى التعليم & r \\
\hline$\varepsilon$ & $9 . \leqslant 9$ & r... $\varepsilon$ & - نوع الأسرة & $r$ \\
\hline 7 & 17.09 & r.Tr & - الحالة المهنية & $\varepsilon$ \\
\hline 7 & $1 \% .09$ & $1 . \leqslant 9$ & - الحالة الزواجية & 0 \\
\hline
\end{tabular}

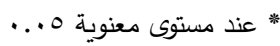

ثالثاً - مصـادر معلومـات الأسـرة الريفيـة المتعقــة بفيروس كورونا المستجد (كوفيد-19 1) ):

يتضــح مـن النتـائج التـي وردت بجـدول (V) توزيسـع

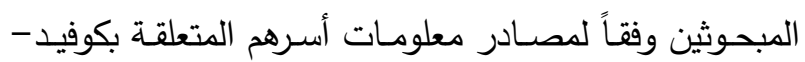

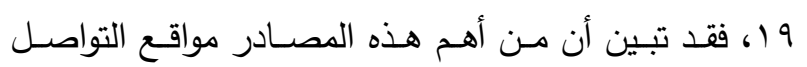
الاجتماعي المختلفة، فقد احتل الترتيب الأول بمتوسط حسابي بلغت قيمته نحو r.Y. Y. ثم تحلاه مصدر الأقارب والجيران، حيث احتل الترتيب الثاني بمتوسط حسابي بلغت قيمته نحو

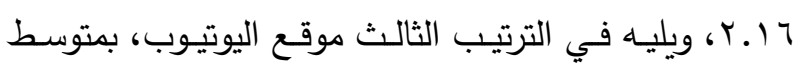

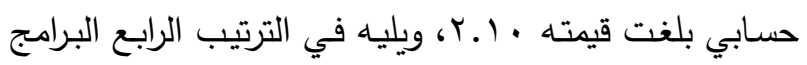

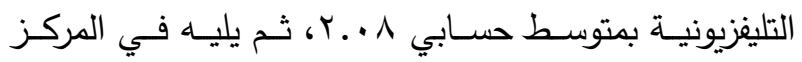

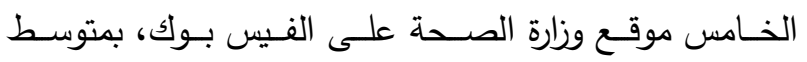
حسابي بو. ا، وجاء في المركز السـادس مصدر الصـف ولف المحلية بمتوسط حسابي ب جـ 1، في حين أن البرامج الإذاعية

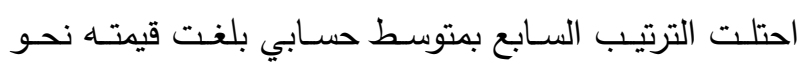
$.1 .0 \mathrm{~V}$

ونسـتتتج ممـا سـبق توضـيحه انتشـار اسـتخدام شـبكة المعلومات العنكبوتية بالمجتمع الريفي، والذي أصبح أحد أهم

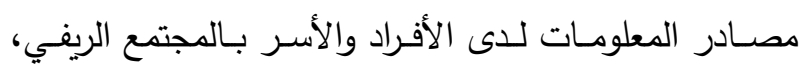
ويتضح ذلك من خلال المصادر التي احتلت الترتيب الأول،

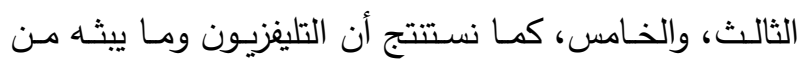

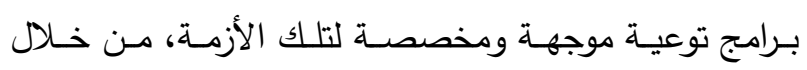
الفضـائيات المتعددة، حيث يعتبر التلفزيون أحد أهم وسـائل
وهي أكبر من مثيلتيها الجدولية والتي تبلغ (99.0)، عند

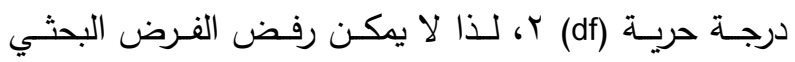
البـديل، ويمكـن رفض الفـرض الإحصــئي الخـاص بهـذا المتغيـر، ويمكن تفسير تلـك النتيجـة مـن خـلال أن التعليم بصفة عامة من شأنه أن يرفع من درجـة وعي الأفراد، كما يجعلهم قادرين على قيادة اسرهم وبالتالي التأثير في أفراد الأسرة، ولاسيما أن مـا يقرب من 11 ا 1 \% فقط لم يكملوا

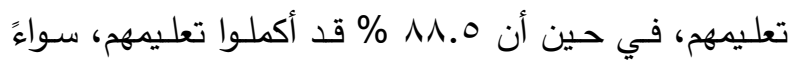
كان تعليم زراعي أم غير زراعي، كما سبق الإشارة إليه في الجزء الخاص بوصف العينة، وهي نسبة ليست بالقليلة، وهذا مـا يفسر تتفيذ أسر المبحوثين للممارسـات الرشيدة لمواجهة تلك الأزمة، وذلك للصلة الواضحة بين التعليم والوعي. كما يتضـح من نفس الجدول عدم وجود علاقة معنويـة بين المتغير التابع وباقي المتغيرات الوصفية المدروسة التي

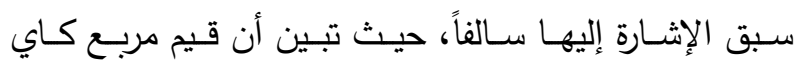

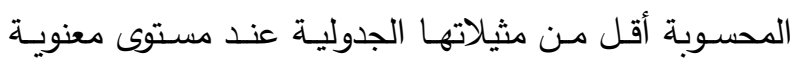
○. . . مبنـاءً عليه يمكن رفض الفرض البحثي البديل، ولا يمكن رفض الفـرض الإحصـائي الخـاص بتلـك المتغيـرات والذي ينص على "عدم وجود علاقة بين مستوى تنفيذ الأسرة

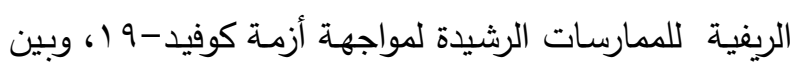
كل من: النوع، نوع الأسرة، الحالة المهنية، والحالة الزواجية". 


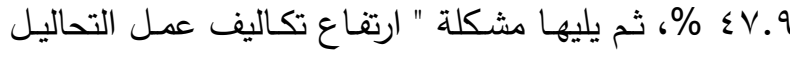

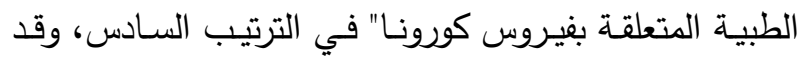
بلغت نسبتها 7. . ؛ \%، ثم جاءت في الترتيب السابع مشكلة

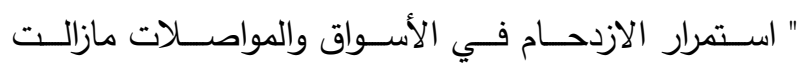

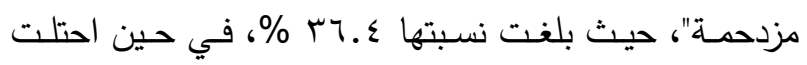

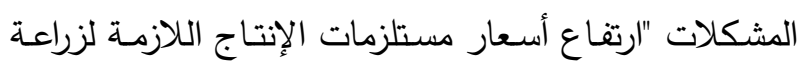

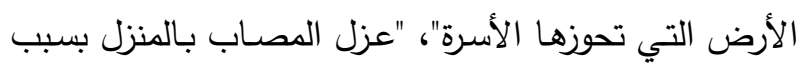
الرفض لاستكمال علاجهم بالمستثفيات"، و"تكدس واستمرار

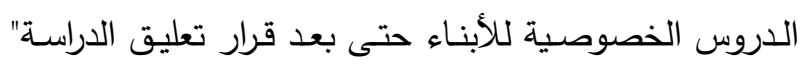

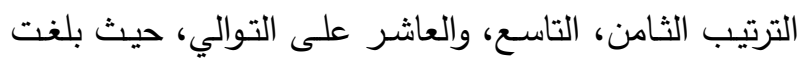

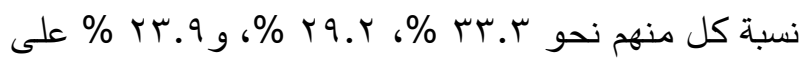

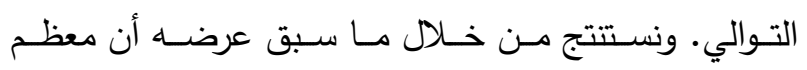
المعوقات والمشكلات التي تعاني منها الأسرة الريفية، والتي أدلى بها أرباب الأسر من المبحوثين تتعلق في الدقام الأول

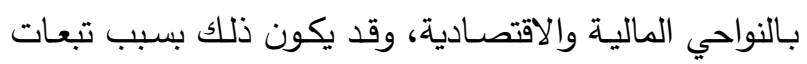
تلك الأزمة مثل الالتزام بالمكوث بالمنزل وعدم الخروج إلا في بادي

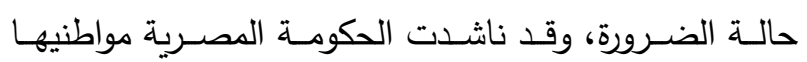
بالالتزام بذلك خـلال فترة منتصف الأزمة تقريباً خلال الفترة

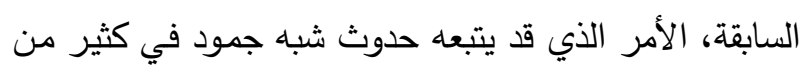

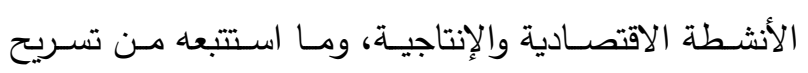

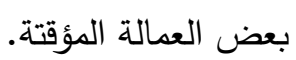

الترفيها والتثقيف لكل أسرة بالمجتمع الريفي، ومـن الجدير

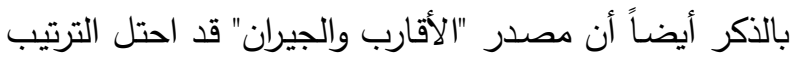

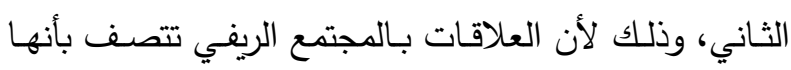

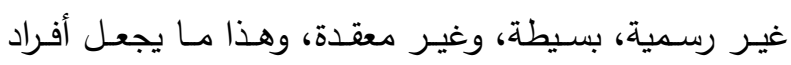

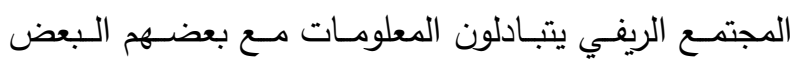

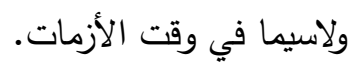

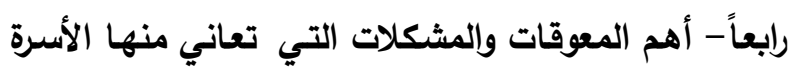

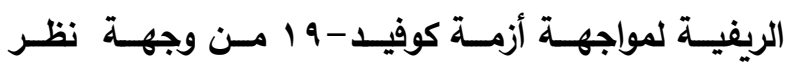

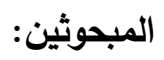

يتبين من النتائج التي وردت بجدول (^) آراء المبحوثين

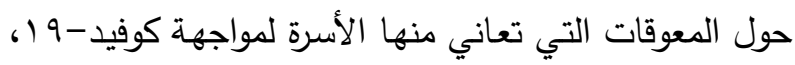

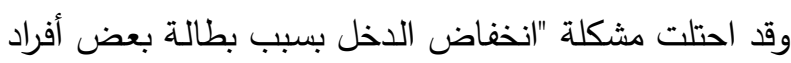

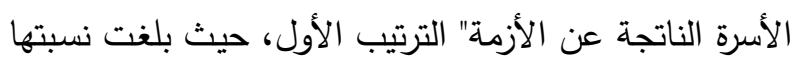

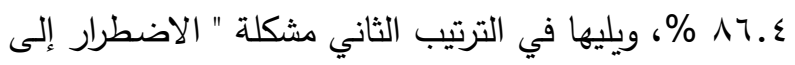

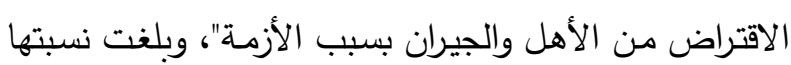

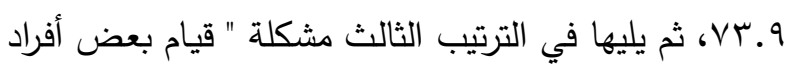

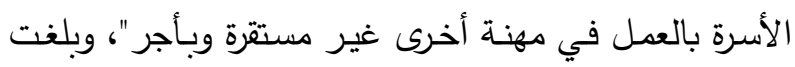

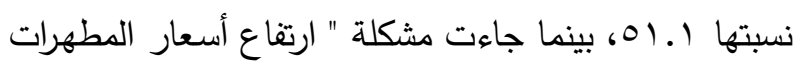

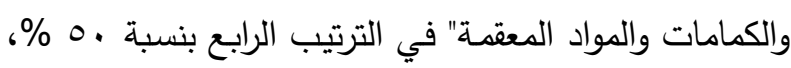

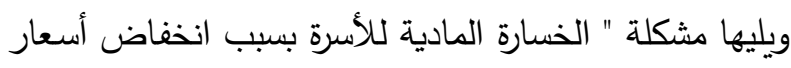

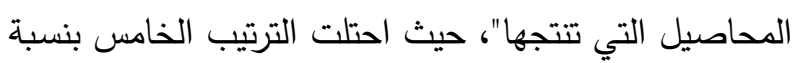

\section{جدول v. توزيع المبحوثين وفقاً لمصادر معلومات أسرهم المتعلقة بفيروس كورونا المستجد (كوفيد-9 (1) (ن=9 9)}

\begin{tabular}{|c|c|c|c|c|c|c|c|c|}
\hline \multirow[t]{2}{*}{ الترتيب } & \multirow{2}{*}{ الحسابي } & \multicolumn{2}{|c|}{ نادرا } & \multicolumn{2}{|c|}{ أحيانا } & \multicolumn{2}{|c|}{ دائما } & \multirow{2}{*}{ المعلومادر } \\
\hline & & $\%$ & تكرارات & $\%$ & تكرارات & $\%$ & تكرارات & \\
\hline السابع & $1.0 \mathrm{~V}$ & $09 . \varepsilon$ & ov & rr.q & rt & $17 . V$ & 17 & - البرامج الإذاعية \\
\hline الرابع & r... & rV.l & ry & rv.o & צ & ro.s & $r \varepsilon$ & - البرامج التليفزيونية \\
\hline السادس & $1.7 r$ & T). & 09 & $1 \leq .7$ & $1 \leq$ & $r r . q$ & r & - الصحف المحلية \\
\hline 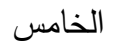 & 1.94 & $1 \wedge . \wedge$ & 11 & 79.1 & TV & $11 . \varepsilon$ & 11 & - موقع وزارة الصحة على الفيس بوك \\
\hline الأول & T. Tr & $r r . q$ & r & $r \cdot . r$ & rq & $\varepsilon 0.1$ & $\varepsilon \varepsilon$ & - مواقع التواصل الاجتماعي المختلفة \\
\hline 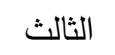 & r.l. & rA. & rV & ( & r & rᄉ.o & rv & - موقع اليوتيوب \\
\hline 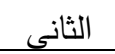 & r.17 & rv.o & ד r & $9 . \varepsilon$ & .9 & or.1 & 01 & - الأقَارب والجيران \\
\hline
\end{tabular}




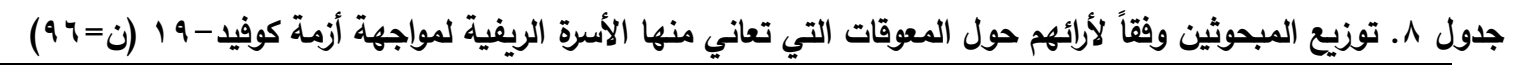

\begin{tabular}{|c|c|c|c|c|}
\hline الترتيب & $\%$ & 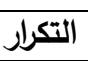 & آراء المبحوثين حول المعوقات التي تعاني منها الأسرة لمواجهة كوفيد-19 & r \\
\hline 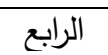 & $0 . .$. & $\sum \wedge$ & ارتقاع أسعار المطهرات والكمامات والمواد المعقة. & 1 \\
\hline 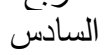 & $\varepsilon . .7$ & rq & ارتفاع تكاليف عمل التحاليل الطبية المتعلقة بفيروه & r \\
\hline 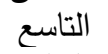 & rq. & rᄉ & عزل الكصاب بالمنزل بَّبب الرفض لاستكمال علاجهح بالمستشفيات. & r \\
\hline 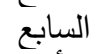 & r. & ro & استمرار الازدحام فى الأسواق والمواصلات مازالت مزدحمة. . & $\varepsilon$ \\
\hline 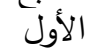 & ᄉ५.ร & r & انخفاض الاخل بسبب بطالة بعض أفراد الأسرة الناتجة عن الأزمة. & 0 \\
\hline 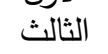 & 01.1 & $\varepsilon 9$ & قيام بعض أفراد الأسرة بالعمل فى مهنة أخرى غير مستقرة وبأجر أقل. & 7 \\
\hline 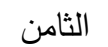 & 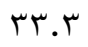 & r & ارتقاع أسعار مستلزمات الإنتاج اللازمة لزراع & $\checkmark$ \\
\hline 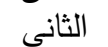 & $V r .9$ & V) & الاضطرار إلى الاقتراض من الأهل والجيران بـ & $\wedge$ \\
\hline 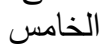 & $\varepsilon \vee .9$ & $\leqslant\rceil$ & الخسارة المادية للأسرة بسبب انخفاض أسعار الدحاصيل التى تنتجها. & 9 \\
\hline العاشر & $r$ r.q & r & تكدس واستمرآ الدروس الخصوصية للأبناء حتى بعد قرار تعليق الدراسة. & 1. \\
\hline
\end{tabular}

" المصدر : جمعت وحسبت من بيانات البحث.

r. بتوفير مستلزمات الإنتاج الزراعي بسعر مخفض"، "مراقبـة

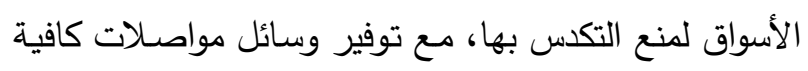

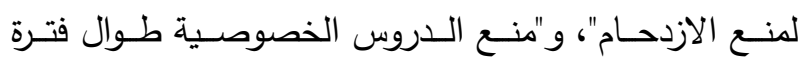
الأزمـة" الترتيب السـابع، والثامن، والتاسـع على الترتيب، وقد

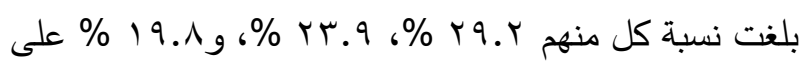
الترتيب. ونستتتج مما سبق أن أغلب الحلول المقترحة من قِبِل

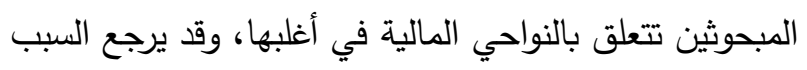

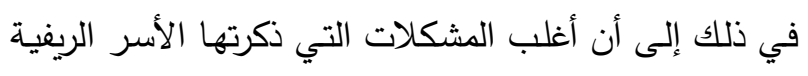
على لسان أرباب الأسر من المبحوثين أيضاً تتعلق بالنواحي

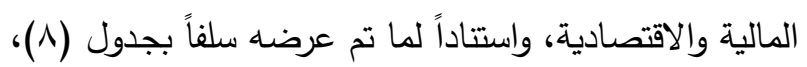
فأعلب الحلـول المـكورة تعتمــ بشكل أساسـي على تمكين

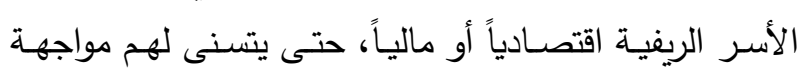

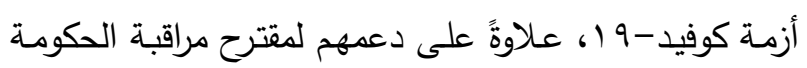

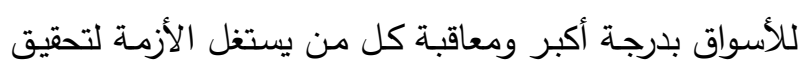

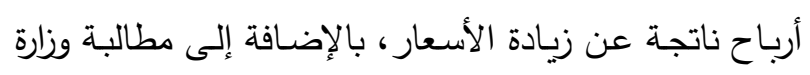

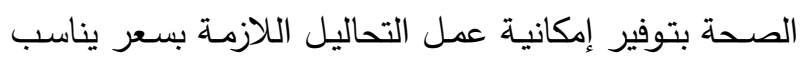
الفئات الفقيرة.
خامساً- العلول المقترحة للتغلب على المعوقات التي تعاني منها الأسرة الريفية لمواجهة أزمة كوفيد-9 1 من وجهة نظرالمبحوثين: تشـير النتـائج الـواردة بجدول (9) إلـى آراء المبحوثين حول الحلول المقترحة للتغلب على المعوقات التي تعاني منها الأسرة لمواجهة الأزمسة، حيث جاء اقتراح "تقديم المساعدات الماديـة لكل الأسرة الفتيرة، وعدم الاكتفاء بمسـاعدة بعضـها لألهاء فقط" في الترتيب الأول، وقد بلغت نسبته ^.79 \% و ويليه في الترتيب الثاني اقتراح "مراقبة الحكومـة للأسعار ومعاقبة ولتبة كل مـن يستخل الأزمـة بـدفع غرامـة ماديـة رادعـة"، بنسـبة

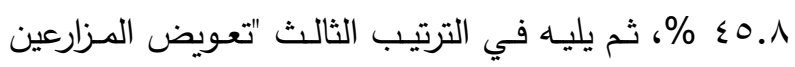
مادياً بسبب خسارتهم في المحصول مع وجود الأزمة" بنسبة

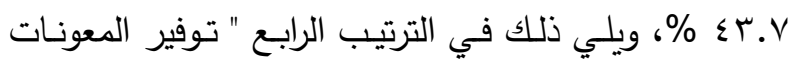

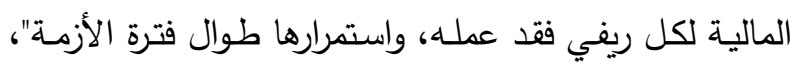

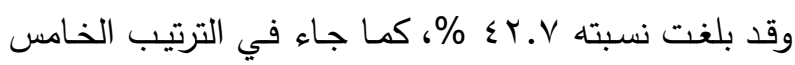
اقتراح "تيسير وزارة الصـحة عمـل التحاليـل الطبيـة اللازمـة بسعر يناسب الفئات غير القادرة" بنسبة ه. م \% \%، ويليه في الترتيـب السـادس اقتراح "إتاحسة اسـتكمال عـلاج المصـابين بالمستشفيات بدلاً من المنزل لتجنب انتشار العدوى"، بنسبة إنبات 


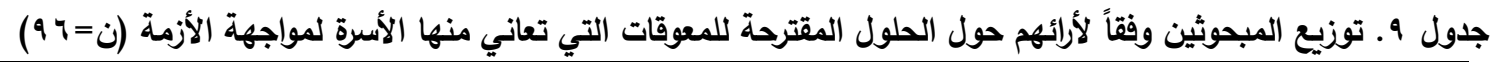

\begin{tabular}{|c|c|c|c|c|}
\hline الترتيب & $\%$ & 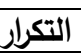 & الحلول المقترحة للمعوقات التى تعانى منها الأسرة لمواجهة أزمة كوفيد-19 & م \\
\hline الثاني & $\varepsilon 0.1$ & $\varepsilon \varepsilon$ & مراقبة الحكومة للأسعار ومعاقبة كل من يستغل الأزمة بدفع غرامة مادية رادعة. & 1 \\
\hline 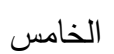 & rᄉ.० & re & تيسير وزارة الصحة عمل التحاليل الطبية اللازمة بسعر يناسب الفئات غير القادرة. & r \\
\hline 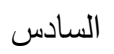 & rV.l & rч & إتاحة استكمال علاج المصابين بالمستثفيات بدلا من المنزل لتجنب انتثار العدوى. & r \\
\hline 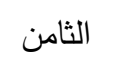 & $r$ r.q & r & مراقبة الأسواق لمنع التكدس بها، مع توفير وسائل مواصلات كافية لمنع الازدحام. & $\varepsilon$ \\
\hline الرابع & $\varepsilon r . V$ & «1 & توفير المعونات المالية لكل ريفى فقد عمله، واستمرارها طوال فترة الأزمة. & 0 \\
\hline 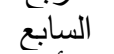 & rq. & rᄉ & قيام الجمعية الزراعية بتوفير مستلزمات الإنتاج الزراعى بسعر مخفض. & 7 \\
\hline الأوز & 79.1 & TV & تقديم المساعدات المادية لكل الأسرة الفقيرة، وعدم الاكتفاء بمساعدة بعضها فقط. & $\checkmark$ \\
\hline 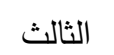 & $\varepsilon r . \vee$ & $\varepsilon r$ & تعوبض المزارعين مادياً بسبب خسارتهم فى المحصول & $\wedge$ \\
\hline 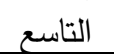 & 19.1 & 19 & ل الخصوصية طوال فترة الأزمة. & 9 \\
\hline
\end{tabular}

ع - ضرورة قيام مجلس رئاسة الوزراء بتكثيف برامج التوعية

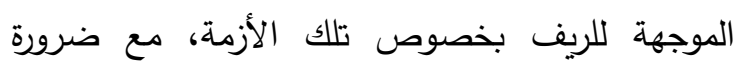
مراعاة أن وسائل التواصل الاجتماعي هي من أكرونر

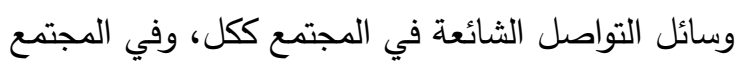
الريفي بصفة خاصة.

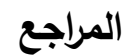

أبو جادو، صالح محمد علي، (T (. ب). سيكولوجية التتشئة

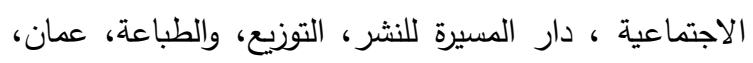

$$
\text { الأردن. - الاجتاع. }
$$

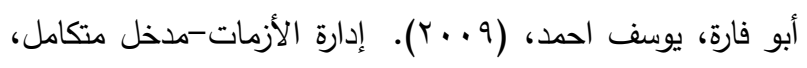
الإثراء للنشر والتوزيع، عمان.

أبو زيد، أحمد، (ع^9 ()). بين الاتجاهات الكلاسيكية والنقدية، الطبعة الثانية، دار المعارف الجامعية، الإسكندرية. الأحمر، أحمد سالم، (ع . . ؟). علم اجتماع الأسرة بين التظظير

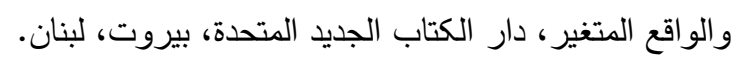

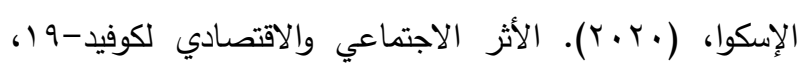

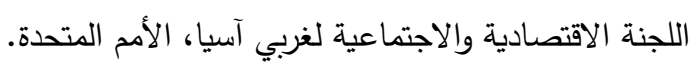

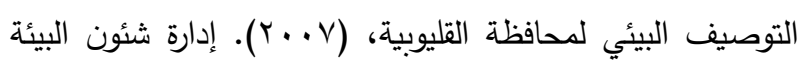

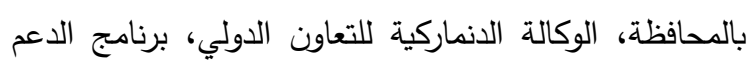
البيئي.

\section{التوصيات}

يتضح فيما يلي أهم التوصيات التي تم استتتاجها، وفقاً لما توصل إليه البحث الراهن من نتائج، والتي قد تساهم في مواجهة تلك الأزمة: ا - القيام بحصر كافة احتياجات الأسر بالمجتمع الريفي وبالأخص فيما يتعلق بالاحتياجات الدوائية والعلاجية، وتوفيرها على نحو يمنع من قيام البعض من استغلال أزمة كوفيد-9 (، وتحقيق هامش ربح يتعدي الضوابط ليط من القانونية والأخلاقية.

r- - ضرورة قيام الجهات المعنية مثل وزارة الصحة، وجهاز حماية المستهلك، بوضع خطة تتميز بالمرونة لتتاسب تلك الفترة العصيبة، بالإضافة إلى تحديث قاعدة البيانات الخاصة بالمجتمع الريفي على فترات قصيرة، لما قد يستجد من تغيرات طارئة وعديدة بخصوص تلك لك الأزمة. r- ض ضرورة قيام وزارة القوى العاملة بحصر العمالة المؤقتة، والعمالة التي تم تسريحها، الفئة المصنفة على أنها بدون عمل، مع التحديث المستمر، حتى يتم تقديم المساعدة

$$
\text { والاعم لمستحقيه. }
$$


فرنانديز، ليونا، (9 (ب). دليل استرشادي، حماية الأطفال أثناء

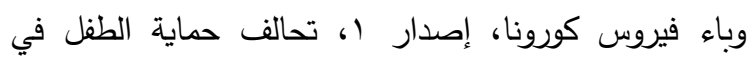
العمل الإنساني، منظمة اليونيسيف، الهند.

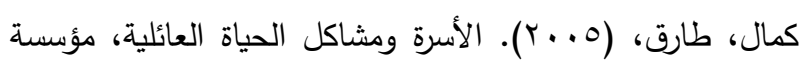
شباب الجامعة الإسكندرية، مصر .

لجنة الأمن الغذائي العالمي، (10 • ب). إطار العمل بشأن الأمن

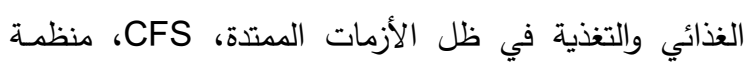

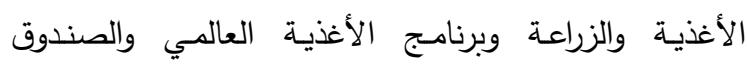

$$
\text { الدولي للتنميـة الزراعيـة. }
$$

مركز المعلومات بالوحدة المحلية بناحية صنافير، (·. (Y). بيانات غير منشورة عن قرية صنافير ، بمحافظة القليوبية.

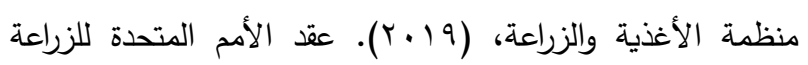

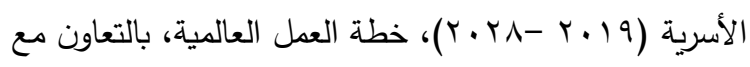

الصندوق الدولي للتنمية الزراعية، روما، ترخيص - CC BY. NC-SA 3.0 IGO

Burgess, Ernest W. and Locke, Harvey J. , (1945). The Family From Institution to Companionship, American sociology series, American book company.

Mitroff Ian I. and Pearson, Christine M ., (1993). From crisis prone to crisis prepared: a framework for crisis management, vol .7'no.1.

Unhale, Shrikrushna Subhash, Quazi Bilal Ansar, Shubham Sanap , Suraj Thakhre, Shreya Wadatkar, Rohit Bairagi, Suraj Sagrule, and K. R. Biyani, (2020). A REVIEW ON CORONA VIRUS

(COVID-19), World Journal of Pharmaceutical and Life Sciences, Vol. 6, Issue 4.

https://www.who.int/health-topics/coronavirus\#tab=tab_1, WHO, (25-11-2020). COVID-19.

حفظي، شيماء، (. . . . ( ). كيف أثرت أزمة كورونا على القطاع https://www.masrawy.com/news/ /2020/5/20 الزراعي

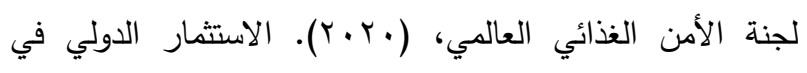
http://www.fao.org/r.r. • الزراعة.
الجمعية التعاونية الزراعية بصنافير، (·. (Y). بيانات غير

منشورة عن النشاط الزراعي لقرية صنافير التابعة لمحافظة

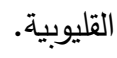

الجهاز المركزي للتعبئة العامة والإحصاء، (1 ( ب ). تقدير عدد

السكان المصريين في الأقسام وفقاً للنوع ومحل الإقامة،

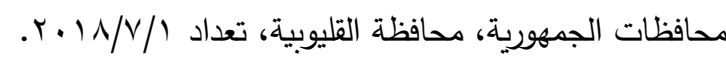

الخطيب، عبدالحميد، (Y . . ץ). نظرة في علم الاجتماع المعاصر،

$$
\text { مطبعة النيل، القاهرة، ج•م•ع. }
$$

الخشاب، أحمد، ( • ( I ). التفكير الاجتماعي، دراسة تكاملية

$$
\text { للنظرية الاجتماعية، دار المعارف، القاهرة. }
$$

الخولي، سناء، (1 . . ץ). الأسرة والحياة العائلية، دار المعرفة الجامعية، الأزاريطة، الإسكندرية.

الصياد، جلال مصطفي، ومصطفي جلال مصطفى، .991:

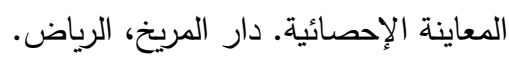

العيساوى، خالد إبراهيم، واللامي، غسان قاسم داود، (0 (ب). إدارة الأزمات- الأسس والتطبيقات، الدار المنهجية للنشر

$$
\text { والتوزبع. }
$$

سعيد، فرج محمد، (919 1) . البناء الاجتماعي والشخصية، الهيئة العامة للكتاب، الإسكندرية، مصر •

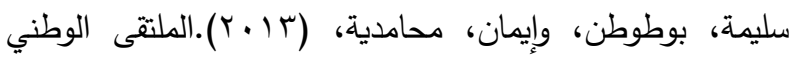
الثاني حول: الاتصال وجودة الحياة في الأسرة، المرأة العاملة والعلاقات الأسرية، قسم العلوم الاجتماعية، كلية العلوم الإنسانية والاجتماعية، جامعة قاصدي مرباح ورقلة، الجزائر . سمير، عبدالله حسن، (ب . . ץ). النظام الاجتماعي من منظور بنائي وظيفي، مجلة جامعة دمشق، المجلد التاسع عشر،

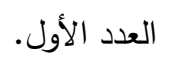

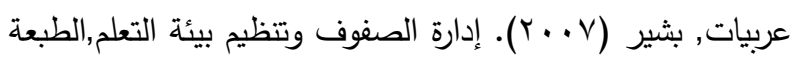

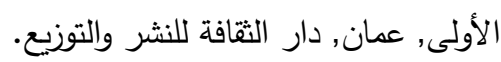




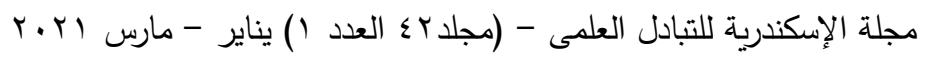

\section{ABSTRACT \\ Rural Family Practices to Confront the COVID-19 Crisis A case Study of a Village in Qalubiya Governorate}

\section{Ehab Abd El- Khalek Mohamed Heikal}

This research aimed to identify the degree of implementation of rational practices (DIRP) by rural family to Confront COVID-19 crisis (RFCC), the significance of relationship between DIRP by RFCC and the studied independent variables, identify information sources of rural family about COVID-19, Identify obstacles facing rural family to face that crisis, and proposed solutions to overcome these obstacles. Data were collected during August 2020, in Sanafeer Village, in Qalubiya Governorate, Through a personal interviews with a simple random sample of 96 respondents, by pretested Questionnaire, results are as follows: $1.66 .7 \%$ of the respondents' families have a (high) DIRP by RFCC, while $19.8 \%$ of the respondents' families have a (medium) DIRP by RFCC, and $13.5 \%$ of the respondents' families have a (low) DIRP by RFCC, 2. Statistically significant relationships were found between DIRP by RFCC and: Age, degree of exposure to mass media, degree of tendency towards preserving the environment, total monthly spending, size of agricultural holdings (at level 0.05), number of years of formal education, and degree of rationalization of consumption (at level 0.01), With Pearsonian correlation coefficient values $(0.202,0.231,0.226$, $0.243,0.218,0.294$, and 0.271 ) respectively, 3. Social media, relatives and neighbors are the most important information sources of rural family about COVID-19, 4. decrease in income due to unemployment of some family members resulting from crisis is one of the most important obstacles facing rural family to confront the Covid-19crisis.

Key words: Rural Family, COVID-19, and Coronavirus. 